OPEN ACCESS

Edited by:

Davide Seveso,

University of Milano-Bicocca, Italy

Reviewed by:

Tali Mass,

University of Haifa, Israel

Fiorella Prada

University of Bologna, Italy

*Correspondence:

Leo L. Chan

leochan@cityu.edu.hk

Specialty section:

This article was submitted to

Aquatic Physiology,

a section of the journal

Frontiers in Physiology

Received: 21 January 2021

Accepted: 09 April 2021

Published: 07 June 2021

Citation:

Dellisanti W, Chung JTH, Chow CFY, Wu J, Wells ML and Chan LL (2021) Experimental Techniques to Assess Coral Physiology in situ Under Global and Local Stressors: Current Approaches and Novel Insights.

Front. Physiol. 12:656562.

doi: 10.3389/fphys.2021.656562

\section{Experimental Techniques to Assess Coral Physiology in situ Under Global and Local Stressors: Current Approaches and Novel Insights}

\author{
Walter Dellisanti, ${ }^{1,2}$, Jeffery T. H. Chung ${ }^{1}$, Cher F. Y. Chow ${ }^{1,3}$, Jiajun $W u^{1}$, Mark L. Wells ${ }^{4,5}$ \\ and Leo L. Chan ${ }^{1,2,6 *}$ \\ 'State Key Laboratory of Marine Pollution, City University of Hong Kong, Kowloon, China, ${ }^{2}$ Department of Biomedical \\ Sciences, City University of Hong Kong, Kowloon, China, ${ }^{3}$ Centre for Biological Diversity, Scottish Oceans Institute, School \\ of Biology, University of St Andrews, St Andrews, United Kingdom, ${ }^{4}$ School of Marine Sciences, University of Maine, Orono, \\ ME, United States, ${ }^{5}$ State Key Laboratory of Satellite Ocean Environment Dynamics, Second Institute of Oceanography, \\ Ministry of Natural Resources, Hangzhou, China, ${ }^{6}$ Hong Kong Branch of Southern Marine Science and Engineering \\ Guangdong Laboratory, Guangzhou, China
}

Coral reefs are declining worldwide due to global changes in the marine environment. The increasing frequency of massive bleaching events in the tropics is highlighting the need to better understand the stages of coral physiological responses to extreme conditions. Moreover, like many other coastal regions, coral reef ecosystems are facing additional localized anthropogenic stressors such as nutrient loading, increased turbidity, and coastal development. Different strategies have been developed to measure the health status of a damaged reef, ranging from the resolution of individual polyps to the entire coral community, but techniques for measuring coral physiology in situ are not yet widely implemented. For instance, while there are many studies of the coral holobiont response in single or limited-number multiple stressor experiments, they provide only partial insights into metabolic performance under more complex and temporally and spatially variable natural conditions. Here, we discuss the current status of coral reefs and their global and local stressors in the context of experimental techniques that measure core processes in coral metabolism (respiration, photosynthesis, and biocalcification) in situ, and their role in indicating the health status of colonies and communities. We highlight the need to improve the capability of in situ studies in order to better understand the resilience and stress response of corals under multiple global and local scale stressors.

Keywords: environmental monitoring, underwater respirometry, fluorometry, photobiology, coral metabolism

\section{INTRODUCTION}

Coral reef ecosystems are hotspots of biodiversity and productivity in the ocean (Roberts et al., 2002) that exceed that of tropical rainforests (Ray, 1988). They provide crucial ecosystem functions and services such as providing goods for subsistence and economic fisheries, coastline protection from storms, and centers of the growing field of ecotourism (Cesar et al., 2003; Knowlton et al., 2010; Van Zanten et al., 2014). As a key habitat-forming taxa, corals are 
critical to both reef systems and the coastal human populations that rely on them, and it is imperative to accelerate advances to ensure the longevity and survival of corals and coral reefs.

Coral reefs have drastically declined worldwide in the last 30 years because of recruitment failures, reduced growth rates, and acute and chronic mortalities (Hughes et al., 2011, 2019), with only a fraction expected to survive in their current form over the next three decades in the Indo-Pacific region (Bruno and Selig, 2007; Descombes et al., 2015). One of the most significant and widespread anthropogenic causes of this degradation is the change in climate drivers associated with the rise in atmospheric carbon dioxide $\left(\mathrm{CO}_{2}\right)$ and other greenhouse gases (Goulletquer et al., 2014; Hannah, 2016). Local stressors also go hand in hand with global stressors, such as coastline erosion or development, which threaten the resilience of corals through pollution and sedimentation (D'Angelo and Wiedenmann, 2014; Silbiger et al., 2018; Loiola et al., 2019; Jones et al., 2020).

Increased energy consumption since the Industrial Revolution has led to the highest $\mathrm{CO}_{2}$ levels recorded in the atmosphere since human evolution ( $>410 \mathrm{ppm}$; Dlugokencky and Tans, 2020). Of the multiple greenhouse gases [such as $\mathrm{N}_{2} \mathrm{O}, \mathrm{CH}_{4}$, or chlorofluorocarbons (CFCs)] affecting global biogeochemical cycles, biodiversity, and human health (Galloway et al., 2004; Bustamante et al., 2012), $\mathrm{CO}_{2}$ has been the most relevant to marine ecology because of its dual role in marine heatwaves (Gruber, 2011) and ocean acidification (Ciais et al., 2013; Figure 1). Overall average seawater temperatures in tropical regions have increased by almost $1^{\circ} \mathrm{C}$ over the past 100 years and are projected to continue increasing at $1-2^{\circ} \mathrm{C}$ per century (Kuffner et al., 2015). Increased seawater temperatures are a major contributor to coral bleaching and are considered as the limiting factor for coral survival (Hughes et al., 2017b, 2019). Roughly half of the $\mathrm{CO}_{2}$ emitted into the atmosphere dissolves into the surface ocean, reacting with water to form several dissolved inorganic components of the carbonate system (Zeebe and Wolf-Gladrow, 2001) and lowering seawater $\mathrm{pH}$ (Anthony et al., 2008). In comparison with pre-Industrial Revolution levels, seawater $\mathrm{pH}$ has decreased by approximately 0.1 (Caldeira and Wickett, 2003), which equates to roughly $30 \%$ increase in acidity and may decrease further by 0.06 to 0.32 based on emission scenarios (Ciais et al., 2013). This process of ocean acidification is particularly disruptive to marine organisms like reef-building hard corals that create calcium carbonate skeletons, increasing the energy requirements for growth and survival (Anthony et al., 2008; Cohen and Holcomb, 2009; Eyre et al., 2014). Thus, corals and coral reefs may be significantly more vulnerable than previously thought when considering the combined effects of ocean acidification and warming (Hoegh-Guldberg et al., 2007; Pandolfi et al., 2011).

Although climate drivers are widely recognized as dominating factors in coral loss and reef ecosystem shifts (Hughes et al., 2017b), localized stressors also are impacting coral health, where a survival-resilience pattern is observable in urban subtropical reefs subjected to several anthropogenic stressors (Heery et al., 2018). Here, there are indications that stresstolerant hard coral species have been selected to foster more resistant though less diverse reefs (Darling et al., 2012). Impacts from eutrophication, increased turbidity, and lowered dissolved oxygen significantly affect coral metabolism, changing energy pathways and reef ecology (Figure 1). A coral as a holobiont includes diversity functional, genomic, and potential epigenetics traits that regulate its ecological plasticity under an environmental change. But not all coral species showed the same response patterns under anthropogenic threats.

Turbid water conditions commonly occur within inshore shallow coastal waters (Browne et al., 2014), owing to the collective interactions of river runoff and the natural re-suspension of sediments (e.g., tides or storms) as well as anthropogenic activities (e.g., ship wakes, coastline modification, and storm and other sewage discharge). The adaptive responses that corals require to survive these conditions are both stressful and energetically costly (Brown and Bythell, 2005), utilizing energy that otherwise would be put towards growth and reproduction. One consequence of increased turbidity is the reduction of the in situ irradiance and thereby photosynthesis, while high levels of settling sediments can hinder feeding or smother coral polyps (Fabricius, 2005). The resulting decreases in photosynthetic efficiency and increases in respiration lower the daily productivity of corals [measured as the ratio of photosynthesis to respiration $(\mathrm{P} / \mathrm{R})]$. This decreased productivity, in turn, lowers the coral nutritional energy reserves (e.g., reduced lipids content and changes in lipids class composition), which can lead to mortality (Weber et al., 2012; Jones et al., 2020). Lower productivity also can increase coral susceptibility to infection and bleaching (Anthony et al., 2007), generating community- and ecosystem-level impacts. In contrast, corals associated with urban developments are frequently exposed to acute sedimentation but appear to escape tissue mortality by better acclimation to low light conditions (Dubinsky et al., 1984) and by increasing their feeding rates to offset energy deficits from photosynthesis (Anthony and Fabricius, 2000). However, any increased frequency or severity of acute sedimentation contributes additional stress to corals that can be functioning near the limits of their physiological tolerances (Bessell-Browne et al., 2017; Loiola et al., 2019; Jones et al., 2020).

Although increased planktonic production can enhance the food supply for corals, very high photosynthetic production rates can generate hyperoxic conditions in reef waters that can cause coral damage and photorespiration (Mass et al., 2010). At best, hyperoxic conditions may shift coral energy use into the production of antioxidants rather than calcification (Wijgerde et al., 2014). In contrast, low oxygen concentrations also challenges coral survival, stimulating metabolic acclimation through the expression of hypoxia-inducible factors in corals (Alderdice et al., 2021). There are few reports of hypoxic events and dead zones in the tropical coral reef environments, though episodic or seasonal hypoxia has been recently linked to bleaching and mortality in deeper water corals (Altieri et al., 2017).

The anthropogenically derived increased inputs of nutrients and organic matter in coastal regions have degraded many coral reefs, and this cultural eutrophication might exacerbate the effect of global warming on coral survival (Silbiger et al., 2018; DeCarlo et al., 2020). The nutrient gradient affects the nutritional 


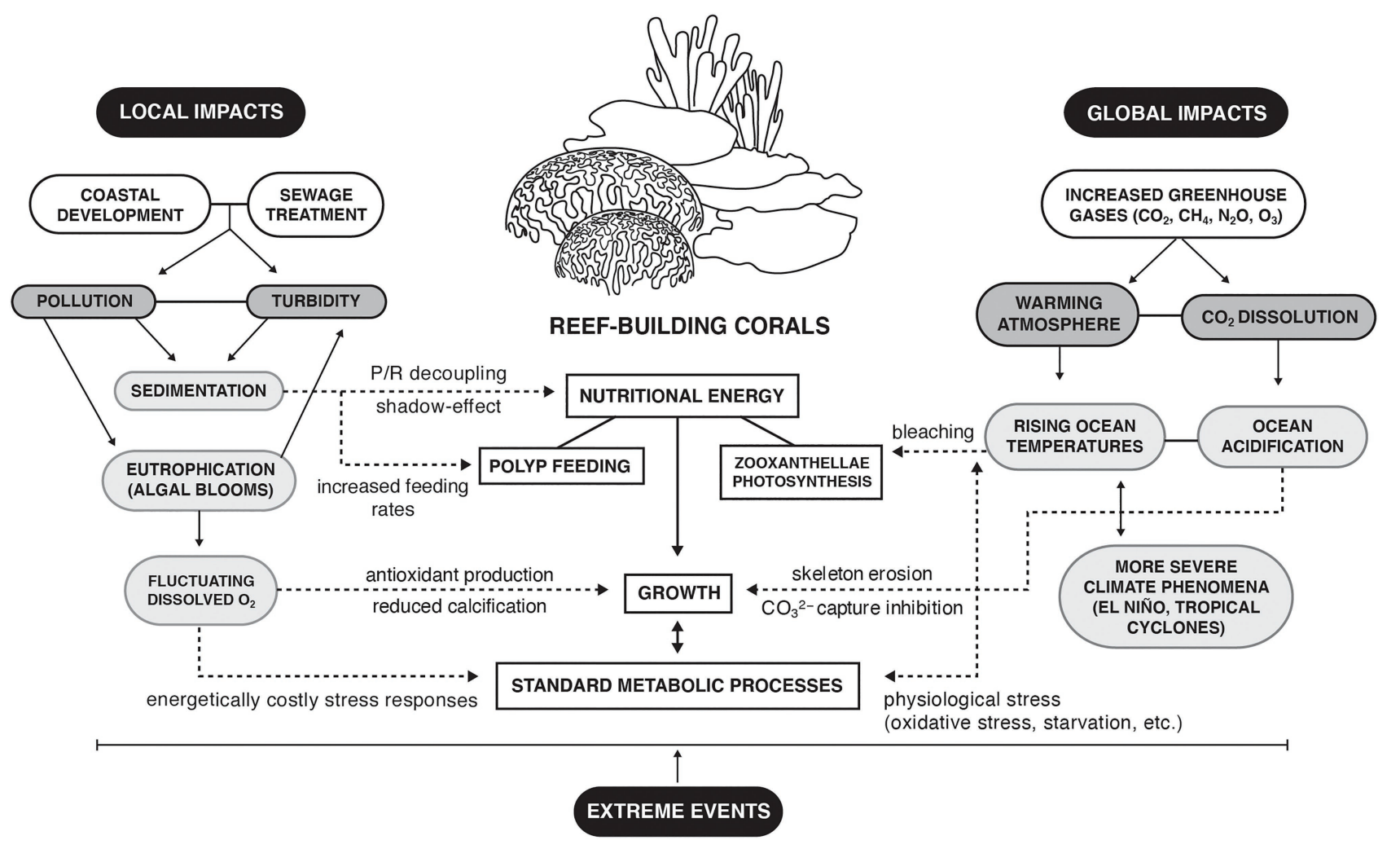

FIGURE 1 | Local and global impacts affecting the nutritional energy of reef-building corals. Full lines indicate direct interactions; dotted lines indicate indirect interactions.

status of corals, in particular when the calcification rate is reduced but heterotrophy enhanced under high nutrient loading (Sawall et al., 2011). Indeed, traces of nitrate pollution can be found in both hard and soft corals through the analysis of radioisotopes $\delta^{15} \mathrm{~N}$ in the tissue (Baker et al., 2011; Duprey et al., 2017) and $\delta^{13} \mathrm{C}$ as an estimate of particulate organic matter ingestion (Baker et al., 2010; Conti-Jerpe et al., 2020). At the community level, a shift from net community calcification (NCC) to dissolution can occur under high nutrient conditions (Silbiger et al., 2018), due to combination of direct and indirect responses of corals. Indeed, nutrient enrichment might negatively affect the physiological performance of coral metabolism, increase the productivity of reef macroalgae, or both, inducing a cascade of change in the coral ecosystems (D'Angelo and Wiedenmann, 2014; Silbiger et al., 2018). Eutrophic conditions can increase the productivity of reef waters by increasing food availability (e.g., particulate matter; Fabricius, 2005), although macroalgae, turf, and bioeroders can inhibit competitively the coral recruitment (D’Angelo and Wiedenmann, 2014). However, several factors influencing the susceptibility to eutrophication have to be included, such as hydrodynamic connectivity and location (Fabricius, 2011). Even so, Sawall et al. (2011) found higher photosynthetic rates of coral endosymbionts nearshore along an anthropogenic driving inshore-offshore nutrient gradient, showing that eutrophication effects on coral may not always be negative.
Gaining knowledge of the stress responses of corals and their effects on reef ecology, along with the pathways to best minimize these impacts, depends on two related tasks: understanding coral health from polyp-endosymbiont symbiosis to the community level and achieving early detection of the onset of the stress responses. The first provides the foundation for studying and developing potential mitigation and managements strategies, and the second is crucial for implementing these strategies soon enough to help minimize impacts.

While most early studies of an environmental change on coral health focused on the effects of single drivers (e.g., temperature, ocean acidification, and turbidity), their interactive effects require addressing multiple stressor effects on physiological processes at the holobiont level if we are to comprehensively understand their impacts on coral communities. Some of these drivers have major effects (e.g., temperature and light), but there undoubtably are other interactions that can affect the resistance and recovery response of coral communities, factors critical for reef management and proactive preventative planning. However, our current understanding of coral stress responses is largely based on experimental manipulation studies in laboratory systems that are poor representations of their natural habitats. In situ studies, by either SCUBA or automated sensors, could provide a better understanding of local and global impacts, but only a few recent studies have undertaken the logistical 
complexities of studying fine-scale physiological processes of corals in situ recently (Roth et al., 2019; Cyronak et al., 2020; Srednick et al., 2020). The primary objective of this review is to summarize the current strategies for quantifying aspects of coral metabolism to highlight the benefits of non-destructive methodologies. A list of recommendations is provided that would expand the efficacy of underwater studies for improving local knowledge and better understanding of how corals respond to stressors.

\section{OVERVIEW OF THE CORAL METABOLISM}

\section{Metabolic Responses at Coral Polyp Level}

The concept of the coral as a "holobiont" was introduced in the 2000s, whereby the coral comprises not only the animal polyps but also the associated symbiotic organisms, including photosynthetic endosymbionts, bacteria, viruses, fungi, and protists (Rohwer et al., 2002; Rosenberg et al., 2007). These have a fundamental role in nutrient and energy acquisition processes of coral polyps (Peixoto et al., 2017), genome evolution in the coral host and microbial partners, maintaining holobiont homeostasis, and the overall health of the holobiont (Thompson et al., 2015). The functional diversity of these microbes contributes to the stress response and acclimation to changing conditions, e.g., high seawater temperature and bleaching events (Jones et al., 2008; Hume et al., 2016).

The family Symbiodiniaceae includes several genera of dinoflagellates, which reside in the tissue of corals and other marine organisms (LaJeunesse et al., 2018). The coralSymbiodiniaceae association is an obligate symbiosis for the coral, where the photosynthetic dinoflagellates provide the coral oxygen and energy in the form of glucose for aerobic respiration (Muscatine, 1998; Gardella and Edmunds, 1999). While most of the oxygen arising from photosynthesis is immediately utilized in coral respiration (Kuhl et al., 1995; Al-Horani et al., 2003a,b), the excess oxygen is released to the surrounding seawater throughout the day (Yonge et al., 1932; Finelli et al., 2006; Al-Horani et al., 2007; Mass et al., 2010), supporting the oxygen availability on the reef. Therefore, at night, corals must acquire oxygen from the surrounding environment to fuel the respiration process (Al-Horani et al., 2007). As a consequence, the energy acquisition follows a circadian pattern where endosymbiontderived photosynthesis is dominant during the day while polypguided respiration is dominant at night.

This continuous loop is stable under normal conditions, but the symbiotic dynamics within the coral holobiont are changing rapidly in the Anthropocene (Hughes et al., 2017a). Temperature-induced stress damages a key protein (D1) in the dinoflagellate photosystem II within the dinoflagellate (PSII; Hill et al., 2011), inactivating the Rubisco center (Lilley et al., 2010), affecting the production of ATP (Franklin et al., 2004), and leading to the overproduction of reactive oxygen species that can induce damaging conditions for both the endosymbiont and coral host. The increased frequency and severity of temperature anomalies will lead to negative consequences for coral survival (Anthony et al., 2008; Randall and Szmant, 2009). Under warming and eutrophic conditions, coral host-endosymbiont relationship may shift from a mutualistic to parasitic strategy with respect to nutritional resource allocation (Lesser et al., 2013). This shift has important implications for the resilience of coral reefs under bleaching conditions, where decreases in net primary productivity of the holobiont mainly from increased respiration in the host, with little apparent metabolic cost to the endosymbiont (Douglas, 2008; Baker et al., 2018).

The coral symbioses also can be influenced by other types of stress related to environmental changes. The impact of high seawater $\mathrm{pCO}_{2} /$ low $\mathrm{pH}$ on corals is highly variable, where it can stimulate growth and photosynthetic efficiency in certain Symbiodiniaceae species (Brading et al., 2011). In other cases, increasing $\mathrm{pCO}_{2}$ had no measurable effect on net photosynthesis (gross photosynthesis - respiration) but decreased biocalcification rates (Comeau et al., 2017). Similarly, elevated concentration of nitrates $\left(\mathrm{NO}_{3}{ }^{-}\right)$or phosphate $\left(\mathrm{PO}_{4}{ }^{3-}\right)$ can stimulate both photosynthesis and respiration rates in corals, but not necessarily result in a concomitant increase in net biocalcification (Silbiger et al., 2018). Such imbalance between photosynthetic energy supply and biocalcification (as biologically induced formation of $\mathrm{CaCO}_{3}$ ) may indicate increasing competition for dissolved inorganic carbon (DIC) between coral host and endosymbionts under conditions of high production. Adding further complexity to these responses, ammonia $\left(\mathrm{NH}_{4}^{+}\right)$enrichment appears to support coral resistance to thermal stress, unlike enrichments of $\mathrm{NO}_{3}{ }^{-}$, which can lead to increased levels of reactive species and oxidative damage (Fernandes de Barros Marangoni et al., 2020).

Bleaching, where the endosymbionts may decrease their chlorophyll content or be ejected from the coral host, signals severe physiological consequences arising from oxidative stress and starvation, leading to reduced respiration rates and energy acquisition (Williams et al., 2017). Though the role of endosymbiont reactive oxygen species production is believed to be fundamental to this process, recent work shows that coral bleaching is more complex than previously thought (Rädecker et al., 2021). Although bleaching can be a reversible condition, it often leads to coral tissue death if sustained too long. However, endosymbionts have developed adaptive mechanisms to limit thermal stress by increasing electron flow in photosystem I as photoprotection (Hoogenboom et al., 2012), thereby limiting the extent of bleaching. Moreover, coral polyps may partially compensate for the lost photosynthetically derived energy during bleaching by enhanced feeding if sufficient prey are available (Anthony et al., 2007).

\section{Responses of the Coral Community}

When magnified across coral tissues, the polyp-level metabolic responses can affect reefs at the community level. Growth of coral colony, or NCC, is measured in terms of the deposition of its calcium carbonate $\left(\mathrm{CaCO}_{3}\right)$ foundation, which is determined largely by coral energy reserves and the need to maintain optimal chemical conditions in the calcifying fluid at the tissue/calcium carbonate interface. Hard corals build 
their skeleton of $\mathrm{CaCO}_{3}$ through the uptake of calcium and carbonate ions from seawater. The reaction occurs in the calicoblastic cells lining the surface where primary crystal secretion occurs (Cohen and Holcomb, 2009) and is facilitated at $\mathrm{pH}$ levels above that of seawater. However, ocean acidification reduces the seawater $\mathrm{pH}$ and the aragonite saturation state (a; Eyre et al., 2014), which can have a strong effect on NCC, along with the balance of organic matter production and respiration, or net community production (NCP; Albright et al., 2015). Moreover, the projected decreases in $\mathrm{pH}$ in the future ocean eventually will affect the stability of existing reef ecosystems, because the $\mathrm{CaCO}_{3}$ formed by corals (aragonite) is more susceptible to dissolution than that formed by other biocalcifying organisms (Shaw et al., 2013). These effects overlay natural seasonal variations in the carbonate chemistry in reef systems, and the question remains of what extent does globally and locally derived ocean acidification have on the seasonal balance of NCP and NCC (Cyronak et al., 2018). However, these estimates remain imprecise, owing to the lack of information about seawater residence time and volume, which would modulate reef chemistry (Courtney et al., 2017). The relationship between host and endosymbionts is exacerbated under the combined effects of global drivers of stress (e.g., temperature, ocean acidification, and atmospheric conditions), leading to lower energy reserves for growth (Anthony et al., 2008; Hughes et al., 2011, 2018; Hoegh-Guldberg, 2014). These, in turn, are combined with local drivers in coastal regions (e.g., increased nutrient, turbidity, and freshwater inputs), causing reduced calcification and oxidative stress and eventually leading to bleaching events (Silbiger et al., 2018; Fernandes de Barros Marangoni et al., 2020).

Even with these impacts though, it is possible for coral communities to recover after destructive events. For example, the coral reef in Kaneohe Bay showed positive NCC and NCP about 1 year after the last drastic bleaching event in 2015 (Courtney et al., 2018), indicating the capacity of local rapid post-bleaching recovery. However, these estimates considered only the abiotic factors, such as carbonate chemistry and oceanographic patterns, without considering potential effects from the benthic community, which would contribute to the depletion or repletion of alkalinity in the coral reef (Page et al., 2017).

Defining the health of corals and coral communities is complex given the array of elements that contribute the status of reef ecosystems. The coral microenvironment comprises ecologically dependent niches (a network made up of bacteria, viruses, and fungi) that supports and regulate the general homeostasis and plasticity of the coral holobiont. But understanding these in situ responses to variable multistressor conditions cannot be adequately informed by just laboratorybased manipulation studies, so the adaptive resilience of coral species and their response thresholds remain only partially understood. It is difficult therefore to chart ways forward for pragmatic and effective steps towards protection and restoration. Overcoming these limitations will depend on applying new in situ observational techniques that can bridge from single organisms to ecosystems and on to regional global scales.

\section{MATERIALS AND METHODS}

We conducted a literature review based on case studies of in situ observations of coral metabolism from published peer-reviewed scientific literature. We included cases involved in original research on direct (e.g., using SCUBA divers, benthic chambers, and optical sensors) underwater measurements of metabolic rates on both coral individuals and coral communities. We excluded sample collections (e.g., coral fragmentation), laboratory experiments, and indirect measurements of metabolic fluxes (e.g., ex situ from sample incubations).

We used the advanced search on Google Scholar to identify studies with the keywords "coral in situ metabolism" and "underwater," excluding the keyword "collection," in articles published between 1991 and 2020. The search yield $(n=2,090)$ was scrutinized, and the literature was manually reviewed to fulfill our selection criteria described above. A final list of 55 studies was included for the analysis in this review (Table 1).

The literature screening was categorized in eight separate categories based on the methodology used (Table 2), including (1) SCUBA fast repetition rate (FRR) fluorometry; (2) SCUBA pulse amplitude modulated (PAM) fluorometry; (3) Clark-type $\mathrm{O}_{2}$ sensors; (4) boundary layer; (5) SCUBA imaging; (6) benthic chambers; (7) submersible chambers; and (8) automated sensors. The database was further classified based on the system type (open, semi-closed, and enclosed); measured parameters $\left[\mathrm{O}_{2}\right.$, photosynthetic efficiency (Fv/Fm), electron transport rate (ETR), and calcification rate (CA)]; sampling frequency (minutes, hours, and days); sampling scale (symbionts, polyp, colony, and community); aim of the study (monitoring and experiment); and environmental stressor considered (light, temperature, turbidity, water quality, water flow, ocean acidification, and time). We ranked the database by publication year (Table 3) and identified the most commonly used techniques for studying in situ coral metabolism. We analyzed the objectives of the studies included in this review (Figure 2) in order to give an overview on the topics mostly studied between 1991 and 2020. Finally, we collated all 55 studies into a map to show the global distribution of experimental studies in situ discussed in this review (Figure 3).

\section{RESULTS}

\section{Methodologies and Objectives for Coral in situ Metabolism}

Several tools and instruments have been developed to noninvasively measure coral metabolic and physiological processes in both field and laboratory studies. These methods can be used to distinguish among healthy and stressed organisms, and the transitions between these states. We focus here on diver-portable technologies, designed to non-destructively estimate energy production and expenditure, such as respirometers and fluorometers. Although there is little consensus about the extent to which apparently healthy corals are adapting to the changing conditions (Baker et al., 2008), measures of 
TABLE 1 | Reference studies discussed in this review, listed in chronological order of publication.

\begin{tabular}{|c|c|}
\hline ID no. & Reference \\
\hline 1 & Patterson et al., 1991 \\
\hline 2 & Gattuso et al., 1993 \\
\hline 3 & Beer et al., 1998 \\
\hline 4 & Ralph et al., 1999 \\
\hline 5 & Gorbunov et al., 2000 \\
\hline 6 & Lombardi et al., 2000 \\
\hline 7 & Lesser and Gorbunov, 2001 \\
\hline 8 & Banaszak et al., 2003 \\
\hline 9 & Winters et al., 2003 \\
\hline 10 & Yates and Halley, 2003 \\
\hline 11 & Levy et al., 2004 \\
\hline 12 & Okamoto et al., 2005 \\
\hline 13 & Wild et al., 2005 \\
\hline 14 & Levy et al., 2006 \\
\hline 15 & Carpenter and Patterson, 2007 \\
\hline 16 & Finelli et al., 2007 \\
\hline 17 & Nakamura and Nakamori, 2007 \\
\hline 18 & Weber et al., 2007 \\
\hline 19 & Frade et al., 2008 \\
\hline 20 & Piniak and Storlazzi, 2008 \\
\hline 21 & Nakamura and Nakamori, 2009 \\
\hline 22 & Schneider et al., 2009 \\
\hline 23 & Carpenter et al., 2010 \\
\hline 24 & Sawall et al., 2011 \\
\hline 25 & McGillis et al., 2011 \\
\hline 26 & Mass et al., 2011 \\
\hline 27 & Kline et al., 2012 \\
\hline 28 & Suggett et al., 2012 \\
\hline 29 & Wangpraseurt et al., 2012b \\
\hline 30 & Haas et al., 2013 \\
\hline 31 & Ferrier-Pagès et al., 2013 \\
\hline 32 & Okazaki et al., 2013 \\
\hline 33 & Roder et al., 2013 \\
\hline 34 & Long et al., 2013 \\
\hline 35 & Wangpraseurt et al., 2014 \\
\hline 36 & Shaw et al., 2014 \\
\hline 37 & Treibitz et al., 2015 \\
\hline 38 & Rovelli et al., 2015 \\
\hline 39 & Camp et al., 2015 \\
\hline 40 & Takeshita et al., 2016 \\
\hline 41 & Chow et al., 2016 \\
\hline 42 & Biscéré et al., 2017 \\
\hline 43 & Albright et al., 2018 \\
\hline 44 & Takeshita et al., 2018 \\
\hline 45 & McMahon et al., 2018 \\
\hline 46 & Roth et al., 2019 \\
\hline 47 & Cyronak et al., 2020 \\
\hline 48 & Ramesh et al., 2019 \\
\hline 49 & de Froe et al., 2019 \\
\hline 50 & Doo et al., 2019 \\
\hline 51 & Pramneechote et al., 2020 \\
\hline 52 & Srednick et al., 2020 \\
\hline 53 & Oh et al., 2020 \\
\hline 54 & Roth et al., 2020 \\
\hline 55 & Dellisanti et al., 2020 \\
\hline
\end{tabular}

metabolic proxies (e.g., variations in dissolved oxygen and $\mathrm{pH}$ ) have been used at both individual coral and coral community scales to infer the metabolic state of benthic ecosystems (Bates et al., 2010). Quantitative links then are sought between these coral indicators and the wider status of the ecosystem physical and biogeochemical indicators.
Laboratory-based studies of coral metabolism in almost all cases involve the destructive sampling of individual colonies or fragments thereof. Although this framework provides crucial knowledge on isolated physiological responses, mechanisms, and pathways under well-controlled conditions, the study conditions cannot comprehensively reflect the stochasticity and cyclical fluctuations in environmental conditions on a reef, nor the cumulative effects of multiple chronic or acute stressors. In the last decades, experimental techniques to study the metabolic status of corals directly in situ have been developed, using specific tools engineered for automated analysis on coral surface and reef communities. Among these, microsensors and benthic chambers for respirometry and fluorometry techniques became the most popular for coral studies over a wide range of topics (Table 2).

The focus of instrumentation development for the in situ study of coral metabolism has shifted over the last three decades, from using fluorometric techniques to estimate endosymbiont photosynthetic efficiency to a more comprehensive investigation of the holobiont relationships in individuals and communities (Table 3). Indeed, through the use of benthic chambers, it is possible to run experimental manipulations of carbon or nutrient fluxes and monitor long-term ecosystem responses via automated sensors. With this shift, the linkages among biogeochemical and physiological processes in corals have greatly improved the understanding of coral ecosystems functioning to where modeling now has a realistic possibility to predict benthic conditions under future climate scenarios (Roth et al., 2019).

Among the objectives of coral physiology studies, 59\% of the published works comprised investigations of the diel or seasonal changes in primary productivity, highlighting that quantification of natural variations in energetic fluxes is a central concern for the assessment of coral conditions (Figure 2). Moreover, coral primary productivity was the only objective of these studies being covered by all methodologies at different sampling scales, from polyp to community. Conversely, $25 \%$ of studies addressed coral physiology under stress, including bleaching responses, environmental changes, and bathymetric change conditions (transplantation). The assessment of recovery of health status was investigated by $9 \%$ of the studies. The remaining papers centered on issues of light limitation, including zonation (4\%) and photo-inhibition (3\%).

\section{Underwater Fluorometry}

The photochemical performance of coral endosymbionts is a key aspect influencing the health of scleractinian corals, so measures of holobiont photophysiology provide a valuable insight into coral metabolic status. Fluorometry can provide this insight in two broad ways: (i) by characterizing the abundance, character, and distribution of light-harvesting pigments (potential energy source) and fluorescent proteins (a sign of immune response and tissue repair) in corals and (ii) as an indicator of how efficiently these pigments are being used to generate energy for the coral, indicated by the photophysiological status of the endosymbiont.

A fundamental measure of coral status is quantification of the light-harvesting pigments of the endosymbionts over time, 
TABLE 2 | Experimental techniques available for in situ monitoring of coral physiological processes.

\begin{tabular}{|c|c|c|c|c|c|c|c|}
\hline Method & System & Parameters & $\begin{array}{l}\text { Sampling } \\
\text { frequency }\end{array}$ & Sampling scale & Aim & Stressor & Reference ID no. \\
\hline $\begin{array}{l}\text { SCUBA FRR } \\
\text { fluorometry }\end{array}$ & Open & ETR, Fv/Fm & Minutes & Symbionts & Monitoring & Light & $5-7,11,14,37$ \\
\hline $\begin{array}{l}\text { SCUBA PAM } \\
\text { fluorometry }\end{array}$ & Semi-closed & ETR, Fv/Fm & Minutes & Symbionts & Monitoring & $\begin{array}{l}\text { Light, temperature, } \\
\text { water flow, water } \\
\text { quality }\end{array}$ & $\begin{array}{l}3,8,9,12,15,16 \\
19,20,24,28,33\end{array}$ \\
\hline $\begin{array}{l}\text { Clark-type } \mathrm{O}_{2} \\
\text { microsensor }\end{array}$ & Open & $\mathrm{O}_{2}$ & Hours & Symbionts, polyp & $\begin{array}{l}\text { Experiment, } \\
\text { monitoring }\end{array}$ & Water quality & 18,49 \\
\hline $\begin{array}{l}\text { Diffusive boundary } \\
\text { layer }\end{array}$ & Semi-closed & $\mathrm{O}_{2}, \mathrm{CA}$ & Minutes & Symbionts, polyp & Monitoring & $\begin{array}{l}\text { Light, water } \\
\text { quality, time }\end{array}$ & $\begin{array}{l}10,25,34,35,38 \\
40\end{array}$ \\
\hline SCUBA imaging & Open & $\mathrm{O}_{2}$ & Hours & $\begin{array}{l}\text { Symbionts, polyp, } \\
\text { colony }\end{array}$ & Monitoring & Light, water quality & $41,48,53$ \\
\hline Benthic chamber & Enclosed & $\mathrm{O}_{2}, \mathrm{CA}$ & Days & Colony & $\begin{array}{l}\text { Experiment, } \\
\text { monitoring }\end{array}$ & $\begin{array}{l}\text { Light, water flow, } \\
\text { water quality, } \\
\text { ocean acidification }\end{array}$ & $\begin{array}{l}1,2,13,21-23,26 \\
30-32,39,42,46 \\
52-55\end{array}$ \\
\hline $\begin{array}{l}\text { Submersible } \\
\text { chamber }\end{array}$ & Enclosed & $\mathrm{O}_{2}, \mathrm{CA}$ & Hours & $\begin{array}{l}\text { Colony, } \\
\text { community }\end{array}$ & $\begin{array}{l}\text { Experiment, } \\
\text { monitoring }\end{array}$ & $\begin{array}{l}\text { Light, water } \\
\text { quality, ocean } \\
\text { acidification }\end{array}$ & $\begin{array}{l}11,14,21,22,26 \\
39,43,50,51\end{array}$ \\
\hline Automated sensors & Open & $\mathrm{O}_{2}, \mathrm{CA}$ & Hours & Community & Monitoring & $\begin{array}{l}\text { Water quality, } \\
\text { ocean acidification }\end{array}$ & $40,43-45,47$ \\
\hline
\end{tabular}

SCUBA FRR, SCUBA-based fast respiration rate fluorometer; SCUBA PAM fluorometry, SCUBA-based pulse amplitude modulation; $\mathrm{O}_{2}$, dissolved oxygen; CA, calcification; ETR, electron transport rate; FV/Fm, maximum quantum yield of photosystem II; Stressors, includes environmental stressors considered in the study; Reference, the identification number is referred to Table 1.

TABLE 3 | Time ranking of published peer-reviewed studies on coral in situ metabolism according to this study.

\begin{tabular}{|c|c|c|c|}
\hline Year & Methodology & Objective & $\begin{array}{l}\text { Sampling } \\
\text { scale }\end{array}$ \\
\hline B41991-2005 & $\begin{array}{l}\text { Fluorometry, benthic, and } \\
\text { submersible chamber }\end{array}$ & $\begin{array}{l}\text { Productivity, diel } \\
\text { change }\end{array}$ & $\begin{array}{l}\text { Polyp, } \\
\text { colony }\end{array}$ \\
\hline 2006-2010 & $\begin{array}{l}\text { Fluorometry, benthic, } \\
\text { chamber and automated } \\
\text { sensors }\end{array}$ & $\begin{array}{l}\text { Diel change, } \\
\text { productivity, physiology } \\
\text { under stress }\end{array}$ & $\begin{array}{l}\text { Colony, } \\
\text { community }\end{array}$ \\
\hline 2011-2015 & $\begin{array}{l}\text { Benthic and submersible } \\
\text { chamber, diffusive } \\
\text { boundary layer }\end{array}$ & $\begin{array}{l}\text { Physiology under } \\
\text { stress, productivity }\end{array}$ & $\begin{array}{l}\text { Colony, } \\
\text { polyp, } \\
\text { community }\end{array}$ \\
\hline 2016-2020 & $\begin{array}{l}\text { Benthic and submersible } \\
\text { chamber, automated } \\
\text { sensors }\end{array}$ & $\begin{array}{l}\text { Seasonal change, } \\
\text { productivity, physiology } \\
\text { under stress }\end{array}$ & $\begin{array}{l}\text { Colony, } \\
\text { community }\end{array}$ \\
\hline
\end{tabular}

whereby decreasing trends may provide early warning of the onset of bleaching events. The underwater fluorescence imaging has been adapted to conduct large-scale in situ assessments of coral reefs, through the detection of chlorophyll and green fluorescent proteins wide spatial scales (Treibitz et al., 2015; Oh et al., 2020). Chlorophyll concentrations are indicative of photo-acclimation, among other things, and green fluorescent proteins may, in addition to being a signal of tissue repair (D'Angelo et al., 2012), contribute to photoprotection in corals; and thus, quantifying these concentrations can provide crucial information on the bleaching susceptibility or resistance of corals (Salih et al., 2000; Kenkel et al., 2011; Roth and Deheyn, 2013). In addition, this imaging technique can also mark early signs of disease as well as help to detect coral juveniles thereby leading to more accurate assessment of coral reef health (Treibitz et al., 2015; Ramesh et al., 2019).
Early in situ studies on coral physiology estimated the rates of photosynthesis and respiration within recirculating chambers by measuring changes in oxygen concentrations (Patterson et al., 1991). While still a highly useful approach (see below), the introduction of variable fluorescence techniques has greatly increased the ability to assess the photophysiology of the endosymbionts and thus provide a sensitive indicator of their metabolic status. With variable fluorescence, very rapid pulses of light are used to probe the photosystems and inform on a number of photosynthetic parameters including the quantum yield of photosystem II (PSI), which is used as a metric for photosynthetic efficiency (Schreiber et al., 1986) and is a key indicator of the physiological status of the endosymbiont. Changes in photosynthetic efficiency provide an early signal of stress, some of which are natural responses to changes in irradiance but become more prolonged and severe when conditions of imminent bleaching occur.

The estimation of the potential quantum yield of PSII as a metric for photosynthetic rates was first applied to underwater organisms by Beer et al (Beer et al., 1998). PAM fluorometer uses light pulses of relatively long duration (300-1,200 ms, 3,000-10,000 mmol photons $\mathrm{m}^{-2} \mathrm{~s}^{-1}$ ) to modify the fluorescence yields, generating multiple turnover for the reduction of PSII, allowing noninvasive chlorophyll fluorescence analysis, quantum yield, and ETR of coral endosymbionts. The introduction of an underwater version of this instrument (Diving-PAM, Walz) facilitated the direct observation of changes in coral health in situ conditions (Ralph et al., 1999). The introduction of in situ PAM fluorometry enabled the construction of photosynthesisirradiance models for corals based on varying sun exposures in reefs (Beer et al., 1998; Ralph et al., 1999). For example, observations of decreased quantum yield during the day 
Primary productivity

$\square$ Physiology under stress

Assessing recovery

Light limitation

Photo-inhibition

Zonation

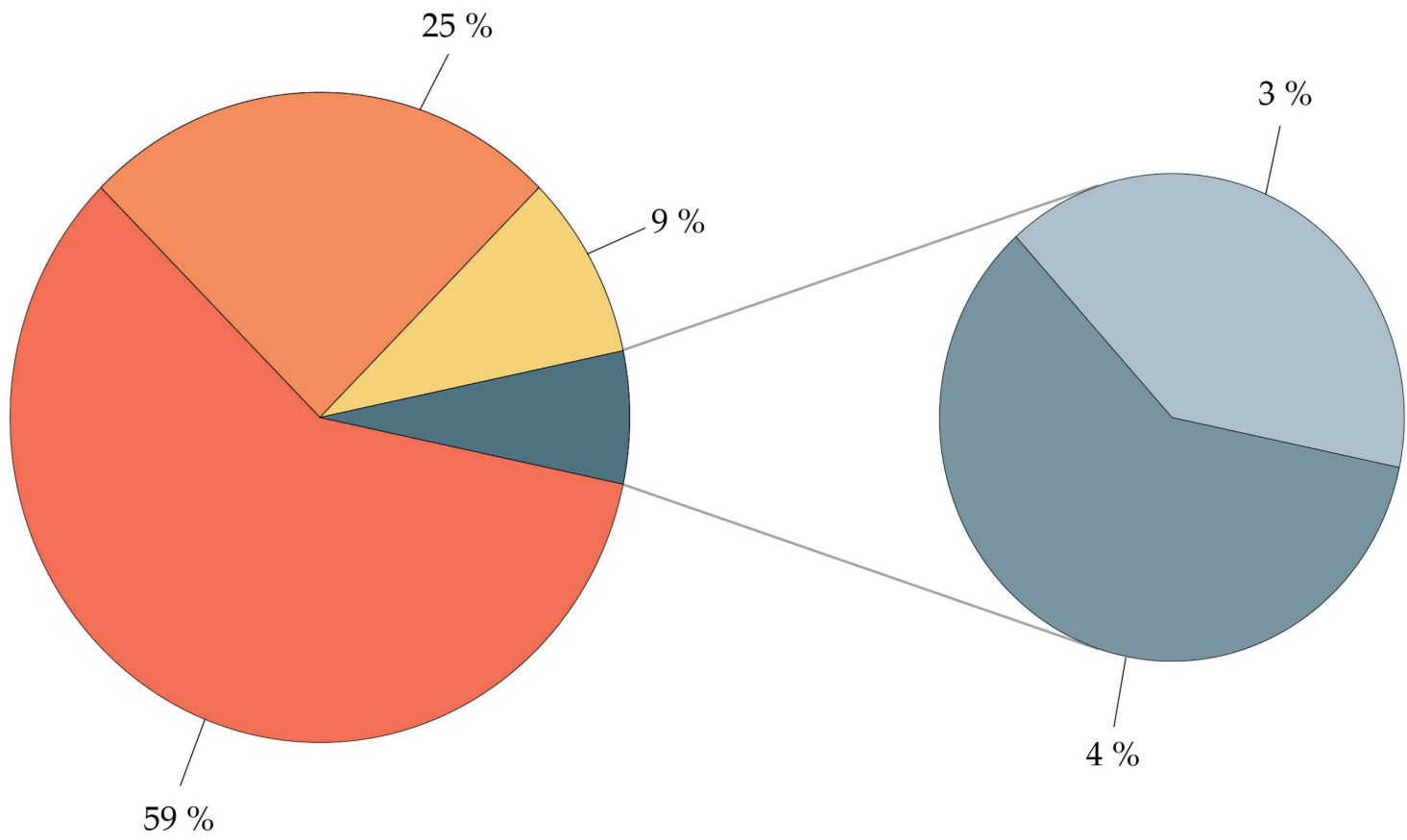

FIGURE 2 | Study objectives of in situ methodologies for the measurement of coral physiology.

reflected photoinhibition through loss of photosynthetic capacity, a response seen in shallow but not deeper water corals (Winters et al., 2003). Similar reduced photosynthetic efficiency has been observed in corals exposed to seasonal turbid conditions (Piniak and Storlazzi, 2008). The use of Diving-PAM continuous monitoring during bleaching events also showed that combined thermal and light stress generated greater reductions in photosynthetic efficiency and was a sensitive indicator of metabolic stress in impacted areas (Roder et al., 2013). Even so, variable responses in the coral community to these stresses suggested coral speciesspecific physiological responses (Banaszak et al., 2003; Okamoto et al., 2005; Frade et al., 2008; Suggett et al., 2012). Further development on PAM technology is the highresolution imaging fluorometry used for analysis of heterogeneity within colonies, from coenosarc tissue to polyp tentacles, but so far, this methodology is not available for underwater studies (Ralph et al., 2005).

A second approach for measuring variable fluorescence is the FRR fluorometer, which uses a different approach to saturate the photochemistry during measurement. Here, shorter (150-400 ms, >20,000 mmol photons $\mathrm{m}^{-2} \mathrm{~s}^{-1}$ ) but more intense light is used to generate a single turnover and reduction of the primary electron acceptor (Kromkamp and Forster, 2003; Suggett et al., 2003). The methodology is more sensitive than PAM fluorometry, which can be beneficial when endosymbiont abundance (or chlorophyll concentrations) is very low in corals. The SCUBA-based FRR fluorometry was developed by Gorbunov et al (Gorbunov et al., 2000) for measuring chlorophyll fluorescence from PSII reaction centers in corals, sea grasses, macroalgae, and algal turfs. FRR fluorometry has been also used to monitor coral physiology during bleaching events and their later recovery (Lombardi et al., 2000; Lesser and Gorbunov, 2001). Although nutrient availability (as nitrogen or iron) and sunlight irradiance were already recognized as the main factors directly affecting photosynthesis in the aquatic ecosystem (Falkowski and Kolber, 1995; Behrenfeld and Kolber, 1999), the use of FRR fluorometry enabled more direct measurements of nutrient limitation effects on photosynthetic efficiency of corals. Indeed, the FRR fluorometry predicted which corals 


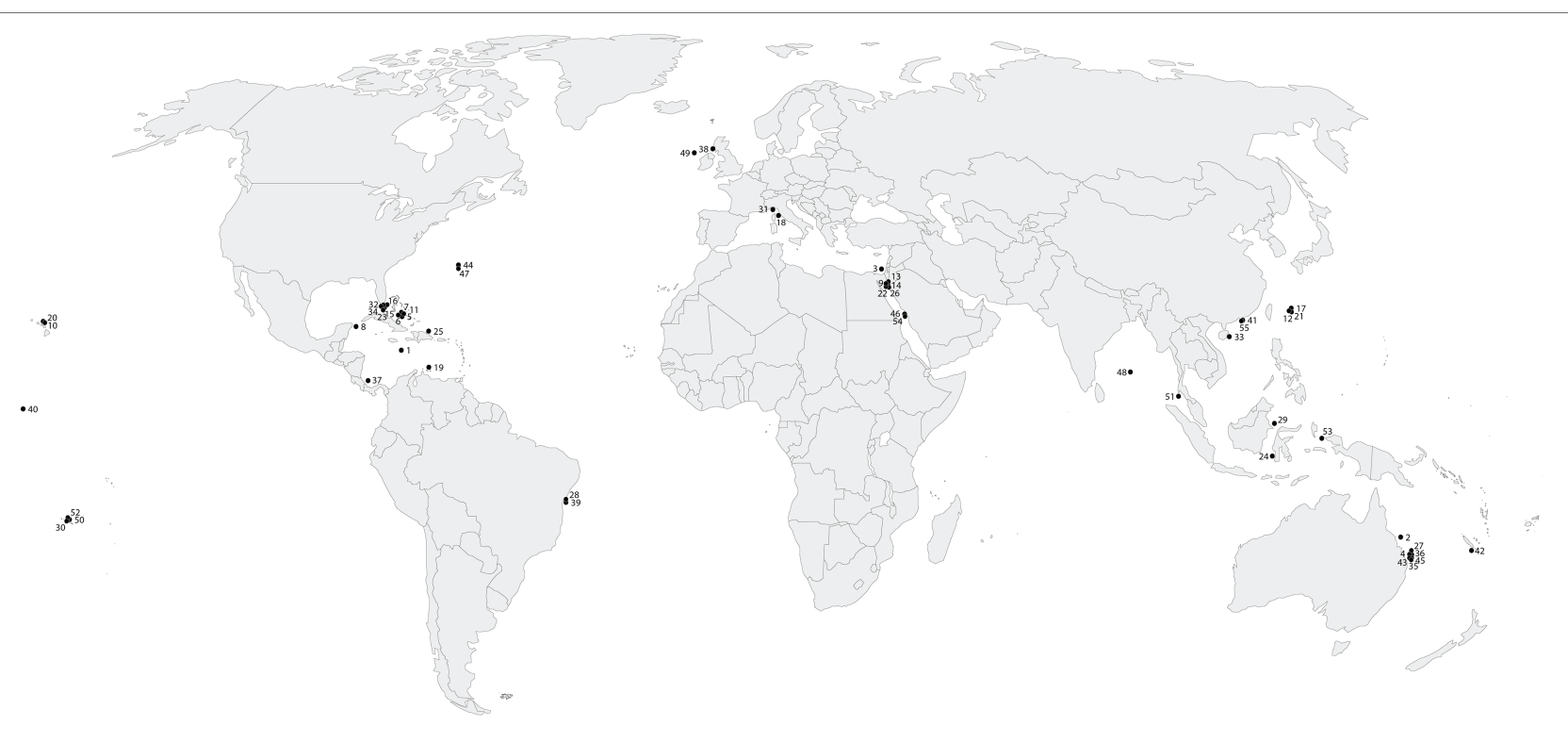

FIGURE 3 | Global map of scientific studies cited in this review. The reference identification numbers are listed in Table 1.

might be more susceptible to bleaching under stress conditions even when no signs of stress are visible, but photosynthetic quantum yield was reduced (Lesser and Gorbunov, 2001).

Submersible chambers have been used to study the evolution of diurnal hysteresis in coral photosynthesis in situ, enabling the comparison of respirometry and fluorometry-based techniques (see below; Levy et al., 2003, 2006). Marked discrepancies were observed, reflecting the importance of different scales of measurements. FRR and PAM fluorometry methods yield signals at the polyp-symbiont scale (Gorbunov et al., 2000), while changes in oxygen concentrations in chambers integrate the whole colony response (Schneider et al., 2009). The assumption here is that the chamber system designs and durations impart no added stress condition on the corals, which appears to be the case in many studies (Camp et al., 2015; Roth et al., 2019; Dellisanti et al., 2020). While it can be argued that chamber methods may be more informative in terms of the holobiont, the portability, ease of operation, and comparatively low cost of fluorescence instruments (Diving-PAM, FRR, and imaging systems) have greatly expanded their use for studying photosynthetic performance of coral symbionts and monitoring diel changes of coral productivity.

\section{Benthic Chambers, Diffusive Flux Methods, and Flow Analysis}

Early in situ studies on coral biology used the strategy of encapsulating single or multiple individuals within closed benthic systems (Patterson et al., 1991). These chamber methods enabled the non-destructive measurement of coral physiological rates through changes in water chemistry to better understand community level responses to perturbation (Patterson et al., 1991; Gattuso et al., 1993). For example, incubation chambers have been used to study in situ coral calcification and photosynthesis rates and showed that ocean acidification can lower the biocalcification rates (Okazaki et al., 2013). Larger incubation systems have enabled measurements of benthic community metabolism as well as conducting in situ experiments, providing a better insight into ecological responses in reefs than can be the focus of studies on host-symbiont relationships (Yates and Halley, 2003; Haas et al., 2013).

The common metrics to assess the health of corals are the levels of photosynthesis by the endosymbionts, respiration of the holobiont, and ideally the rates of biocalcification (or growth). Benthic chambers are well-suited to measure these essential parameters in situ (Wild et al., 2005; Nakamura and Nakamori, 2007; Ferrier-Pagès et al., 2013; Camp et al., 2015). For example, differences in coral metabolism were measured between shallow (reef flat) and deeper area (reef slope) at Ishigaki Island, Japan, with negative net calcification rates being attributed to nighttime decreases in $\mathrm{pH}$ due to benthic respiration (Nakamura and Nakamori, 2009). In another study, Sawall et al. (2011) used benthic chamber to study the coral nutritional status at elevated anthropogenic nutrient loading. The novel incorporation of a transparent 3-L urine bag into the "Flexi-Chamber" design led to an easily managed, low-cost device for use by any underwater scientists, where short incubations are able to detect changes in biological processes absent of any visual signs of coral stress or change in endosymbionts concentration (Camp et al., 2015). A similar benthic chamber design was used to show that abiotic conditions, including light intensity, were drivers of spatialtemporal patterns of reef metabolism, although some limitations on the use of these incubation chambers emerged when applied on large boulder colonies (Pramneechote et al., 2020). Here, the amount of light available for photosynthesis and the energetic budget can vary based on colony shape (micro niches) and the immediate surrounding environment (backscattering light; Wangpraseurt et al., 2014). However, newer designs of noninvasive 
diver-portable in situ incubation chambers $\left(\sim 70 \mathrm{~L}, 0.2-\mathrm{m}^{2}\right.$ area $)$ have been developed to measure biogeochemical processes in both simple (sediments) and structurally complex (corals or rocky bottoms) reef communities, allowing the in situ study of diverse habitats, such as corals, sediments, and seagrass meadows (Roth et al., 2019). The introduction of benthic and submersible chambers has made it possible to link individual metabolic host-symbiont processes to community-wide reef responses, improving the generality and robustness of previous metabolic and physiology studies.

An ambitious program began in mid-1996 to adapt benthic chambers for use as flow respiratory systems to study the in situ responses of coral communities. Using a combination of in situ flow chambers and fluorometric techniques, Shepard et al. (1996) demonstrated how both water flow and temperature combined to influence coral physiology. Later, the "Submersible Habitat for Analyzing Reef Quality" was designed to maintain and measure a turbulent flow of water over benthic substrates for extended periods while measuring temperature, oxygen, salinity, $\mathrm{pH}$, and irradiance (photosynthetically active radiation) and to monitor the daily variations in photosynthesis, respiration, and calcification (Yates and Halley, 2003). This system enabled some of the first studies of the direct influence of high $\mathrm{CO}_{2}$ levels on coral communities in short-term experiments (Yates and Halley, 2003). But the real strength of this approach is the ability to study the ecology and biogeochemistry of coral/ benthic communities and how they may acclimate to altered conditions over multiple days. A similar automated closed chamber was used to study coral responses over a variety of substrate types (Gevaert et al., 2011).

These flow systems have enabled new strategies for in situ investigation of the effects of environmental stressors on reef metabolism, ecology, and biogeochemistry. Flow systems have been used to demonstrate asymmetric patterns of photosynthetic yield across coral colonies (Carpenter et al., 2010), where the upper side has a reduced quantum yield (Carpenter and Patterson, 2007). Other experimental studies have used flow chambers to study coral physiology under chemical enrichment in a benthic chamber experiment (Biscéré et al., 2017), adding new findings on coral responses to high $\mathrm{pCO}_{2}$ and the combined effect of chemical inputs and global warming. Haas et al. (2013) used large collapsible benthic isolation tents (cBITs) to study the integrated responses of corals, macroalgae, and microbes over diurnal cycles, and they showed how the release of algal exudates influenced microbial metabolism and energy transfer to higher trophic levels. Similarly, small benthic chambers enclosing $\sim 70$ L (Roth et al., 2019) were used to study complex benthic structures and to measure coral reef community budgets of primary production over coral-dominated or algae-dominated reef communities (Roth et al., 2020), adding new findings on the biogeochemical cycles of coral reef ecosystems. A common feature of these flow systems is that they commonly require constructing or placement of large or cumbersome structures on the reef, so replicating findings across and among reef systems is difficult. A new diver-portable respirometer [community in situ metabolism (CISME)] enables short-term (minutes) quantification of coral photosynthetic, respiration, and biocalcification rates combined with the ability to study the effects of flow and chemical manipulations (Dellisanti et al., 2020). Although its use has been limited to date, it offers many of the benefits of larger chamber devices but also the ability to assess individual coral colonies across and among reef environments with good accuracy and resolution.

\section{Micro- and Automated Sensors}

While benthic chambers provide a means for studying the community level responses, by design, these systems alter water flow dynamics around the study corals and restrict water exchange sufficiently to enable changes in water chemistry to accumulate (i.e., the measurement signals). It is unclear at what stage these changes in water flow and bulk chemical conditions may begin influencing coral responses. The use of micro- and automated sensors for unenclosed measurements has been developed to help avoid these potential artifacts. These approaches are broadly separated into community-scale and individual coral or polyp scales.

Unenclosed, diffusive boundary layer (DBL) approaches were developed to avoid these potential issues, whereby sensors placed well above the coral interface make unobstructed measurements of vertical gradients in velocity, temperature, and chemical constituents on the open reef to calculate the flux of momentum, heat, and $\mathrm{O}_{2}$ in the boundary layer (McGillis et al., 2011). Use of these unenclosed strategies has revealed new insights into coral metabolism by showing the fluctuations in biologically mediated changes in chemical conditions under different natural regimes of dissolved oxygen, pH, and light intensity (Cyronak et al., 2018; McMahon et al., 2018; Takeshita et al., 2018).

The use of microsensors at coral tissue levels in turn has illustrated how these factors influence and are influenced by the coral-seawater interface (McGillis et al., 2011; Wangpraseurt et al., 2012a, 2014; Long et al., 2013; Takeshita et al., 2016). For example, the oxygen saturation at the coral-water interface fluctuates from supersaturated during daytime due to production by endosymbionts to hypoxic at night from respiration of the holobiont (Shashar et al., 1993; Kuhl et al., 1995; Gardella and Edmunds, 1999). However, despite these broad chemical changes, oxygen microsensors used in the microenvironment of coral-turf and coral-coralline algae showed that low oxygen concentrations were not generally found at the interface of Porites spp., turf algae, and crustose coralline algae (Wangpraseurt et al., 2012a), an observation that illustrated the value of combining microstructure measurements with benthic or flow chamber methods that can take into account multiple reef species.

More microenvironment studies are needed to better understand the metabolic regulation between corals and the surrounding environment (Wangpraseurt et al., 2014). Technological development of microsensors in a modified diveroperated system (Weber et al., 2007) allowed the quantification of irradiance at the coral surface and the measurement of the efficiency of photosynthetic system at polyp and coenosarc microscale (Wangpraseurt et al., 2012b), confirming the ability of corals to adapt to environmental changes, such as temperature 
or irradiance (Brown et al., 2002). On a broader scale, microand automated sensors increasingly have been used in both closed (benthic chamber) and open (reef-scale) approaches to studying coral and reef ecologies. We consider now the subset of unconfined sensor-based studies of whole reef environments.

\section{Reef Scale Experiments}

The study of larger scale reef environments in open or unconfined natural systems was made possible by combining the sensors for measuring both water flow and relevant aspects of water chemistry. A common approach is the DBL method that relies on eddy correlation techniques (Berg et al., 2003), where noninvasive acoustic Doppler velocimeters measuring water flow are coupled with $\mathrm{O}_{2}$ sensors to provide three-dimensional fields of oxygen distribution over benthic environments (Long et al., 2013). This method can examine in situ dynamics of $\mathrm{O}_{2}$ production and consumption (i.e., respiration) in different habitats, including highly productive reef crests relative to reef slopes (Long et al., 2013) as well as cold-water (deep) coral reefs (Rovelli et al., 2015; de Froe et al., 2019). These ecosystemscale measurements show how high oxygen fluxes are possible, even in nutrient-replete environments such as reef slopes and deep waters. The advantage of such techniques has been discussed by Takeshita et al. (2016) who introduced a new autonomous system (the benthic ecosystem and acidification measurement system) for simultaneous measurement of NCP and NCC from a coral reef through the autonomous use of $\mathrm{O}_{2}$ and $\mathrm{pH}$ sensing technology. Using this strategy, Takeshita et al. (2018) showed how seawater carbonate chemistry is strongly driven by local benthic metabolism, and that these effects varied substantially over small-scale habitats, across the entire reef platform, and over seasonal timescales, an important perspective for better assessing the impacts of ocean acidification on these ecosystems.

A comparison between the enclosed and open system approaches showed good general agreement with respect to discrete measurements of oxygen from the gradient flux (GF) method at the DBL and a multiparametric probe in a benthic chamber (Yates and Halley, 2003), although other findings indicate that the GF method can offer more accurate measurements of these fluxes (McGillis et al., 2011). The low physical disruption with DBL methods means both less direct impacts on corals and more spatially integrative observation and interpretation of coral reef responses to changes in the natural environment at colony or community levels. Their smaller infrastructure requirements also make them an attractive strategy for investigations. Even so, these approaches can be complementary. For example, DBL studies show that water flow can be a factor affecting the light-limited photosynthesis in coral colonies (Finelli et al., 2006), and more spatially focused studies have used benthic chambers to show that increased water flow leads to increased calcification rates, carbonate deposition, protein concentration, and endosymbionts density (Mass et al., 2011).

Experiments at reef scale represent a key step forward in the in situ studies of coral responses in the natural environment (Kline et al., 2012; Albright et al., 2018; Doo et al., 2019;
Srednick et al., 2020), but they also have provided the opportunity to quantify reef-scale responses to environmental perturbations. For example, manipulations to lower $\Omega$ a by $\sim 20 \%$ led to a $34 \%$ decrease in NCC consistent with the effect of lower $\mathrm{pH}$ on biocalcification (Albright et al., 2016), although this finding may have been influenced by a high abundance of crustose coralline algae living in the reef community (Albright et al., 2018). Another free ocean $\mathrm{CO}_{2}$ enrichment (FOCE) system was used to incubate coral reef communities at ambient $\mathrm{pCO}_{2}$ (393 $\mu \mathrm{atm})$ and high $\mathrm{pCO}_{2}(949 \mu \mathrm{atm})$, and a decrease in daily NCC by $49 \%$ under high $\mathrm{pCO}_{2}$ was observed over a 21-day experiment, corresponding to $26 \%$ reduction in NCC per unit of $\Omega \mathrm{a}$ (Doo et al., 2019). These results were in line with previous studies on ecosystem-level responses of coral reef communities to ocean acidification level projected in the next century. Indeed, a modification of this experimental approach, the coral-proto free ocean carbon enrichment system, allowed the short-term in situ study of the induced ocean acidification on coral reef organisms and diel changes of the seawater carbonate system (Kline et al., 2012). Srednick et al. (2020) introduced another novel FOCE for spatial and temporal studies on shallow reefs, with the aim of studying a coral reef community in situ under controlled conditions of current and projected levels of $\mathrm{pCO}_{2}$. They directly estimated the hysteresis of seawater carbonate chemistry along a reef transect, using high accuracy and precision measurements of seawater $\mathrm{pH}$, $\mathrm{pCO}_{2}$, and the biological responses of the reef community with high temporal resolution (Srednick et al., 2020). Other high-frequency sampling of coral reef carbonate dynamics and metabolic rates have used automated systems for measurements of alkalinity, $\mathrm{pH}$, and $\mathrm{pCO}_{2}$ at high-frequency sampling (McMahon et al., 2018; Cyronak et al., 2020). Through automated measurements with the slack water and flow respirometry approaches, it is now possible to characterize the net calcification and productivity of a reef system (either reef flats or crests), as well as reveal long-term changes driven by global changes (ocean acidification and global warming) or hysteresis under local changes (Albright et al., 2018; McMahon et al., 2018). However, dissimilarities in the methods used in community metabolism studies (Shaw et al., 2015) create potential uncertainties when applied to coral reefs, in terms of community calcification and seawater carbonate conditions. Limitations of metabolic studies at community level are related to lack of suitable controls, spatial heterogeneities, and thus replicability among sites, as well as confounding factors in open systems, such as the introduction of organisms and differing oceanographic settings in the surrounding reef environments.

\section{DISCUSSION AND CONCLUSION}

We have collated and summarized here the underwater methodologies from 55 studies on coral metabolism and physiology conducted since 1991 (Table 1). The current knowledge of combined effects of local and global stressors comes from a wide breadth of manipulation studies on coral responses under predicted future scenarios but limited in 
representing complex abiotic factors in ecosystems. Interaction among environmental variables, including temporal changes in inorganic carbon chemistry, physical parameters, or nutrient loads, is an important factor affecting the biogeochemistry of coral health (Doo et al., 2019) and can play a key role in population dynamics. Though invaluable as a study tool, manipulation studies are limited in the ability to mimic important spatial-temporal patterns and interactions. On the other hand, comprehensive long-term in situ metabolic measurements still are lacking but nevertheless necessary to understand the energetics and trophodynamics of reef ecosystems.

Laboratory-based studies have provided a strong foundation for understanding coral metabolism and the responses to stress, and they will continue to serve as a primary means of research under controlled conditions. However, the expanding role of in situ-based studies of coral systems is essential for extrapolating and modulating these laboratory-based findings to the temporal and spatial complexity of natural reef and environmental conditions. The advantages of in situ experimental techniques described here relate to the ability for measuring metabolic and biogeochemical properties of different benthic habitats having both simple (sediments) and complex (corals or rocky bottom) structures. Standardization of methods and replication of experimental studies would allow the simultaneous measures of coral health in different locations with the ability to compare the ecosystem functions. However, there are limitations to in situ methodologies. In the case of benthic chambers, there are restrictions to which substrate surfaces are suitable for study, and they are not well suited, even with enhanced flow capabilities, for longer-term monitoring of coral health. These restricted systems also have limited spatial footprints and thus may not adequately account for all benthic of pelagic components (e.g., macroalgae and fish). In the case of DBL approaches, limitations include the needed maintenance and fragility of microsensors, which can limit deployments to shorter duration, or under more quiescent weather conditions.

Long-term continuous observations of coral biological process are critical to the assessment of responses to climate and other anthropogenic drivers and though so far lacking newly developed platforms for general oceanographic study offer this potential moving forward. In particular, autonomous platforms, such as gliders and surface vehicles, are incorporating biogeochemical sensors (i.e., $\mathrm{pCO}_{2}$, dissolved oxygen, $\mathrm{pH}$, and chlorophyll a), able to cover spatial, vertical, and temporal observations (Chai et al., 2020; Cryer et al., 2020). While these autonomous devices are not well suited for shallow reef environments, the advances in sensor development and operational constraints will be valuable in designing systems or autonomous robots that can provide reliable long-term assessments of the status of reef ecosystems. Indeed, autonomous measurements of light, dissolved oxygen, and alkalinity were used to estimate the NCP and NCC in order to evaluate the efficacy of coral restoration in supporting the net ecosystem metabolism (Platz et al., 2020). Autonomous sensors can be used also to measure the seasonal variability in carbonate chemistry and the relationship between carbonate chemistry and biological activity of benthic organisms identifying spatial differences according to different substrates, like corals, seagrasses, or mangroves (Meléndez et al., 2020). These systems are especially important in natural ocean acidification laboratories, such as hydrothermal vents, characterized by naturally high fluctuations of $\mathrm{pH}$ and temperature (Kerrison et al., 2011; Fabricius et al., 2015; Torres et al., 2021).

Co-deployment of multiple instrumentation approaches, from water chemistry and physics to coral physiology, will be needed to ensure both accuracy and logistic practicality in monitoring fluxes of $\mathrm{O}_{2}$, changes of $\mathrm{pH}$, and other aspects of the carbonate system in coral reefs. Even with these accounted for, most studies on coral metabolic rates rely on observation of changes in DIC and alkalinity in a specific (small) area to calculate the carbon fluxes for productivity and biocalcification estimates (Anthony et al., 2011); the movement of seawater flow and aspects of reef heterogeneity cannot be fully taken into account, leading to potentially biased findings that may not adequately reflect natural conditions. Moving forward then, it will be more informative by combining different scales of in situ techniques, such as the application of flow respirometry approaches to estimate carbon fluxes over a small spatial scales and different substrate type within a reef, coupled with reef-scale methods that provide an integrative assessment of the temporal variability in coral productivity and growth (McMahon et al., 2018).

\section{AUTHOR CONTRIBUTIONS}

WD and JC: conceptualization, methodology, formal analysis, and resources. WD: investigation, data curation, and writing original draft preparation. WD, JC, CC, JW, MW, and LC: writing - review and editing. WD and CC: visualization. LC: supervision. JW and LC: project administration and funding acquisition. All authors contributed to the article and approved the submitted version.

\section{FUNDING}

This study was supported by the Hong Kong Branch of Southern Marine Science and Engineering Guangdong Laboratory (Guangzhou; SMSEGL20SC02); the Collaborative Research Fund (C7013-19G) of the Hong Kong Research Grants Council; the National Natural Science Foundation of China (41641047); the Internal Research Project of State Key Laboratory of Satellite Ocean Environment Dynamics, Second Institute of Oceanography, State Oceanic Administration (no. SOEDZZ1702); and the SKLMP Seed Collaborative Research Fund (SCRF/0027).

\section{ACKNOWLEDGMENTS}

The authors thank Florian Roth (University of Helsinki) for the constructive comments and John Hodgkiss for the proofreading. 


\section{REFERENCES}

Albright, R., Benthuysen, J., Cantin, N., Caldeira, K., and Anthony, K. (2015). Coral reef metabolism and carbon chemistry dynamics of a coral reef flat. Geophys. Res. Lett. 42, 3980-3988. doi: 10.1002/2015GL063488

Albright, R., Caldeira, L., Hosfelt, J., Kwiatkowski, L., Maclaren, J. K., Mason, B. M., et al. (2016). Reversal of ocean acidification enhances net coral reef calcification. Nature 531, 362-365. doi: 10.1038/nature 17155

Albright, R., Takeshita, Y., Koweek, D. A., Ninokawa, A., Wolfe, K., Rivlin, T., et al. (2018). Carbon dioxide addition to coral reef waters suppresses net community calcification. Nature 555, 516-519. doi: 10.1038/nature25968

Alderdice, R., Suggett, D. J., Cárdenas, A., Hughes, D. J., Kühl, M., Pernice, M., et al. (2021). Divergent expression of hypoxia response systems under deoxygenation in reef-forming corals aligns with bleaching susceptibility. Glob. Chang. Biol. 27, 312-326. doi: 10.1111/gcb.15436

Al-Horani, F. A., Al-Moghrabi, S. M., and De Beer, D. (2003a). Microsensor study of photosynthesis and calcification in the scleractinian coral, Galaxea fascicularis: active internal carbon cycle. J. Exp. Mar. Biol. Ecol. 288, 1-15. doi: 10.1016/S0022-0981(02)00578-6

Al-Horani, F. A., Al-Moghrabi, S. M., and De Beer, D. (2003b). The mechanism of calcification and its relation to photosynthesis and respiration in the scleractinian coral Galaxea fascicularis. Mar. Biol. 142, 419-426. doi: 10.1007/ s00227-002-0981-8

Al-Horani, F. A., Tambutté, É., and Allemand, D. (2007). Dark calcification and the daily rhythm of calcification in the scleractinian coral, Galaxea fascicularis. Coral Reefs 26, 531-538. doi: 10.1007/s00338-007-0250-x

Altieri, A. H., Harrison, S. B., Seemann, J., Collin, R., Diaz, R. J., and Knowlton, N. (2017). Tropical dead zones and mass mortalities on coral reefs. Proc. Natl. Acad. Sci. 114, 3660-3665. doi: 10.1073/pnas.1621517114

Anthony, K. R. N., Connolly, S. R., and Hoegh-Guldberg, O. (2007). Bleaching, energetics, and coral mortality risk: effects of temperature, light, and sediment regime. Limnol. Oceanogr. 52, 716-726. doi: 10.4319/lo.2007.52.2.0716

Anthony, K. R. N., and Fabricius, K. E. (2000). Shifting roles of heterotrophy and autotrophy in coral energetics under varying turbidity. J. Exp. Mar. Biol. Ecol. 252, 221-253. doi: 10.1016/S0022-0981(00)00237-9

Anthony, K. R. N., Kleypas, J., and Gattuso, J. P. (2011). Coral reefs modify their seawater carbon chemistry - implications for impacts of ocean acidification. Glob. Chang. Biol. 17, 3655-3666. doi: 10.1111/j.1365-2486.2011.02510.x

Anthony, K. R. N., Kline, D. I., Diaz-Pulido, G., Dove, S., and Hoegh-Guldberg, O. (2008). Ocean acidification causes bleaching and productivity loss in coral reef builders. Proc. Natl. Acad. Sci. U. S. A. 105, 17442-17446. doi: 10.1073/ pnas.0804478105

Baker, D. M., Freeman, C. J., Wong, J. C. Y. Y., Fogel, M. L., and Knowlton, N. (2018). Climate change promotes parasitism in a coral symbiosis. ISME J. 12, 921-930. doi: 10.1038/s41396-018-0046-8

Baker, A. C., Glynn, P. W., and Riegl, B. (2008). Climate change and coral reef bleaching: an ecological assessment of long-term impacts, recovery trends and future outlook. Estuar. Coast. Shelf Sci. 80, 435-471. doi: 10.1016/j. ecss.2008.09.003

Baker, D. M., Jordán-Dahlgren, E., Maldonado, M. A., and Harvell, C. D. (2010). Sea fan corals provide a stable isotope baseline for assessing sewage pollution in the Mexican Caribbean. Limnol. Oceanogr. 55, 2139-2149. doi: 10.4319/lo.2010.55.5.2139

Baker, D. M., Kim, K., Andras, J. P., and Sparks, J. P. (2011). Light-mediated $15 \mathrm{~N}$ fractionation in Caribbean gorgonian octocorals: implications for pollution monitoring. Coral Reefs 30, 709-717. doi: 10.1007/s00338-011-0759-x

Banaszak, A. T., Ayala-Schiaffino, N., Rodriguez-Romàn, A., Enriquez, S., and Iglesisas-Prieto, R. (2003). Response of Millepora alcicornis (Milleporina: Milleporidae) to two bleaching events at Puerto Morelos Reef, Mexican Caribbean. Rev. Biol. Trop. 51, 57-66.

Bates, N. R., Amat, A., and Andersson, A. J. (2010). Feedbacks and responses of coral calcification on the Bermuda reef system to seasonal changes in biological processes and ocean acidification. Biogeosciences 7, 2509-2530. doi: 10.5194/bg-7-2509-2010

Beer, S., Ilan, M., Eshel, A., Weil, A., and Brickner, I. (1998). Use of pulse amplitude modulated (PAM) fluorometry for in situ measurements of photosynthesis in two Red Sea faviid corals. Mar. Biol. 131, 607-612. doi: $10.1007 /$ s002270050352
Behrenfeld, M. J., and Kolber, Z. S. (1999). Widespread iron limitation of phytoplankton in the south pacific ocean. Science 283, 840-843. doi: 10.1126/ science.283.5403.840

Berg, P., Røy, H., Janssen, F., Meyer, V., Jørgensen, B., Huettel, M., et al. (2003). Oxygen uptake by aquatic sediments measured with a novel non-invasive eddycorrelation technique. Mar. Ecol. Prog. Ser. 261, 75-83. doi: 10.3354/meps261075

Bessell-Browne, P., Negri, A. P., Fisher, R., Clode, P. L., Duckworth, A., and Jones, R. (2017). Impacts of turbidity on corals: the relative importance of light limitation and suspended sediments. Mar. Pollut. Bull. 117, 161-170. doi: 10.1016/j.marpolbul.2017.01.050

Biscéré, T., Lorrain, A., Rodolfo-Metalpa, R., Gilbert, A., Wright, A., Devissi, C., et al. (2017). Nickel and ocean warming affect scleractinian coral growth. Mar. Pollut. Bull. 120, 250-258. doi: 10.1016/j.marpolbul.2017.05.025

Brading, P., Warner, M. E., Davey, P., Smith, D. J., Achterberg, E. P., and Suggett, D. J. (2011). Differential effects of ocean acidification on growth and photosynthesis among phylotypes of Symbiodinium (Dinophyceae). Limnol. Oceanogr. 56, 927-938. doi: 10.4319/lo.2011.56.3.0927

Brown, B., and Bythell, J. (2005). Perspectives on mucus secretion in reef corals. Mar. Ecol. Prog. Ser. 296, 291-309. doi: 10.3354/meps 296291

Brown, B. E., Dunne, R. P., Goodson, M. S., and Douglas, A. E. (2002). Experience shapes the susceptibility of a reef coral to bleaching. Coral Reefs 21, 119-126. doi: 10.1007/s00338-002-0215-Z

Browne, N., Precht, E., Last, K., and Todd, P. (2014). Photo-physiological costs associated with acute sediment stress events in three near-shore turbid water corals. Mar. Ecol. Prog. Ser. 502, 129-143. doi: 10.3354/meps 10714

Bruno, J. F., and Selig, E. R. (2007). Regional decline of coral cover in the Indo-Pacific: timing, extent, and subregional comparisons. PLoS One 2:e711. doi: 10.1371/journal.pone.0000711

Bustamante, M. M. C., Nardoto, G.B., Pinto, A.S., Resende, J. C. F., Takahashi, F. S. C., and Vieira, L. C. G. (2012). Potential impacts of climate change on biogeochemical functioning of Cerrado ecosystems. Braz. J. Biol. 72, 655-671. doi: 10.1590/S1519-69842012000400005

Caldeira, K., and Wickett, M. E. (2003). Anthropogenic carbon and ocean pH. Nature 425:365. doi: 10.1038/425365a

Camp, E. F., Krause, S. L., Santos, L. M. F., Naumann, M. S., Kikuchi, R. K. P., Smith, D. J., et al. (2015). The "Flexi-Chamber": A novel cost-effective in situ respirometry chamber for coral physiological measurements. PLoS One 10:e138800. doi: 10.1371/journal.pone.0138800

Carpenter, L. W., and Patterson, M. R. (2007). Water flow influences the distribution of photosynthetic efficiency within colonies of the scleractinian coral Montastrea annularis (Ellis and Solander, 1786); implications for coral bleaching. J. Exp. Mar. Biol. Ecol. 351, 10-26. doi: 10.1016/j.jembe.2007.05.022

Carpenter, L. W., Patterson, M. R., and Bromage, E. S. (2010). Water flow influences the spatiotemporal distribution of heat shock protein 70 within colonies of the scleractinian coral Montastrea annularis (Ellis and Solander, 1786) following heat stress: implications for coral bleaching. J. Exp. Mar. Biol. Ecol. 387, 52-59. doi: 10.1016/j.jembe.2010.02.019

Cesar, H., Burke, L., and Pet-Soede, L. (2003). The economics of worldwide coral reef degradation. International Coral Reef Action Network Available at: https://agris.fao.org/agris-search/search.do?recordID=GB2013202743 (Accessed September 22, 2020).

Chai, F., Johnson, K. S., Claustre, H., Xing, X., Wang, Y., Boss, E., et al. (2020). Monitoring ocean biogeochemistry with autonomous platforms. Nat. Rev Earth Environ. 1, 315-326. doi: 10.1038/s43017-020-0053-y

Chow, M. H., Tsang, R. H. L., Lam, K. Y., and Ang, P. Jr. (2016). Quantifying the degree of coral bleaching using digital photographic technique. J. Exp. Mar. Biol. Ecol. 479, 60-68. doi: 10.1016/j.jembe.2016.03.003

Ciais, P., Sabine, C., Bala, G., Bopp, L., Brovkin, V., and Canadell, J. (2013). "Carbon and other biogeochemical cycles," in Climate Change 2013 the Physical Science Basis: Working Group I Contribution to the Fifth Assessment Report of the Intergovernmental Panel on Climate Change. eds. T. F. Stocker, D. Qin, G.-K. Plattner, M. Tignor, S. K. Allen and J. Boschung et al. (Cambridge University Press), 465-570.

Cohen, A., and Holcomb, M. (2009). Why corals care about ocean acidification: uncovering the mechanism. Oceanography 22, 118-127. doi: 10.5670/ oceanog.2009.102

Comeau, S., Edmunds, P. J., Lantz, C. A., and Carpenter, R. C. (2017). Daily variation in net primary production and net calcification in coral reef 
communities exposed to elevated $\mathrm{pCO}_{2}$. Biogeosciences 14, 3549-3560. doi: 10.5194/bg-14-3549-2017

Conti-Jerpe, I. E., Thompson, P. D., Wong, C. W. M., Oliveira, N. L., Duprey, N. N., Moynihan, M. A., et al. (2020). Trophic strategy and bleaching resistance in reef-building corals. Sci. Adv. 6, 5443-5453. doi: 10.1126/sciadv.aaz5443

Courtney, T. A., De Carlo, E. H., Page, H. N., Bahr, K. D., Barro, A., Howins, N., et al. (2018). Recovery of reef-scale calcification following a bleaching event in Kāne’ohe Bay, Hawai'i. Limnol. Oceanogr. Lett. 3, 1-9. doi: 10.1002/lol2.10056

Courtney, T. A., Lebrato, M., Bates, N. R., Collins, A., De Putron, S. J., Garley, R., et al. (2017). Environmental controls on modern scleractinian coral and reef-scale calcification. Sci. Adv. 3:e1701356. doi: 10.1126/sciadv.1701356

Cryer, S., Carvalho, F., Wood, T., Strong, J. A., Brown, P., Loucaides, S., et al. (2020). Evaluating the sensor-equipped autonomous surface vehicle C-worker 4 as a tool for identifying Coastal Ocean acidification and changes in carbonate chemistry. J. Mar. Sci. Eng. 8:939. doi: 10.3390/jmse8110939

Cyronak, T., Andersson, A. J., Langdon, C., Albright, R., Bates, N. R., Caldeira, K., et al. (2018). Taking the metabolic pulse of the world's coral reefs. PLoS One 13:e0190872. doi: 10.1371/journal.pone.0190872

Cyronak, T., Takeshita, Y., Courtney, T. A., DeCarlo, E. H., Eyre, B. D., Kline, D. I., et al. (2020). Diel temperature and $\mathrm{pH}$ variability scale with depth across diverse coral reef habitats. Limnol. Oceanogr. Lett. 5, 193-203. doi: $10.1002 / \mathrm{lol} 2.10129$

D’Angelo, C., Smith, E. G., Oswald, F., Burt, J., Tchernov, D., and Wiedenmann, J. (2012). Locally accelerated growth is part of the innate immune response and repair mechanisms in reef-building corals as detected by green fluorescent protein (GFP)-like pigments. Coral Reefs 31, 1045-1056. doi: 10.1007/ s00338-012-0926-8

D'Angelo, C., and Wiedenmann, J. (2014). Impacts of nutrient enrichment on coral reefs: new perspectives and implications for coastal management and reef survival. Curr. Opin. Environ. Sustain. 7, 82-93. doi: 10.1016/j. cosust.2013.11.029

Darling, E. S., Alvarez-Filip, L., Oliver, T. A., Mcclanahan, T. R., and Côté, I. M. (2012). Evaluating life-history strategies of reef corals from species traits. Ecol. Lett. 15, 1378-1386. doi: 10.1111/j.1461-0248.2012.01861.x

DeCarlo, T. M., Gajdzik, L., Ellis, J., Coker, D. J., Roberts, M. B., Hammerman, N. M., et al. (2020). Nutrient-Supplying Ocean currents modulate coral bleaching susceptibility. Sci. Adv. 6:eabc5493. doi: 10.1126/ sciadv.abc5493

de Froe, E., Rovelli, L., Glud, R. N., Maier, S. R., Duineveld, G., Mienis, F., et al. (2019). Benthic oxygen and nitrogen exchange on a cold-water coral reef in the north-East Atlantic Ocean. Front. Mar. Sci. 6:665. doi: 10.3389/fmars.2019.00665

Dellisanti, W., Tsang, R. H. L., Ang, P. Jr., Wu, J., Wells, M. L., and Chan, L. L. (2020). A diver-portable respirometry system for in-situ short-term measurements of coral metabolic health and rates of calcification. Front. Mar. Sci. 7:571451. doi: 10.3389/fmars.2020.571451

Descombes, P., Wisz, M. S., Leprieur, F., Parravicini, V., Heine, C., Olsen, S. M., et al. (2015). Forecasted coral reef decline in marine biodiversity hotspots under climate change. Glob. Chang. Biol. 21, 2479-2487. doi: 10.1111/gcb. 12868

Dlugokencky, E., and Tans, P. (2020). Global Monitoring Laboratory - Carbon Cycle Greenhouse Gases. US Dep. Commer. NOAA, Glob. Monit. Lab. Available at: www.esrl.noaa.gov/gmd/ccgg/trends (Accessed July 6, 2020).

Doo, S. S., Edmunds, P. J., and Carpenter, R. C. (2019). Ocean acidification effects on in situ coral reef metabolism. Sci. Rep. 9, 1-8. doi: 10.1038/s41598-019-48407-7

Douglas, A. E. (2008). Conflict, cheats and the persistence of symbioses. New Phytol. 177, 849-858. doi: 10.1111/j.1469-8137.2007.02326.x

Dubinsky, Z., Falkowski, P. G., Porter, J. W., and Muscatine, L. (1984). Absorption and utilization of radiant energy by light- and shade-adapted colonies of the hermatypic coral Stylophora pistillata. Proc. R. Soc. Lond. Ser. B Biol. Sci. 222, 203-214. doi: 10.1098/rspb.1984.0059

Duprey, N. N., Wang, X. T., Thompson, P. D., Pleadwell, J. E., Raymundo, L. J., Kim, K., et al. (2017). Life and death of a sewage treatment plant recorded in a coral skeleton $\Delta 15 \mathrm{~N}$ record. Mar. Pollut. Bull. 120, 109-116. doi: 10.1016/j.marpolbul.2017.04.023

Eyre, B. D., Andersson, A. J., and Cyronak, T. (2014). Benthic coral reef calcium carbonate dissolution in an acidifying ocean. Nat. Clim. Chang. 4, 969-976. doi: $10.1038 /$ nclimate2380

Fabricius, K. E. (2005). Effects of terrestrial runoff on the ecology of corals and coral reefs: review and synthesis. Mar. Pollut. Bull. 50, 125-146. doi: 10.1016/j.marpolbul.2004.11.028
Fabricius, K. E. (2011). "Factors determining the resilience of coral reefs to eutrophication: A review and conceptual model," in Coral Reefs: An Ecosystem in Transition. eds. Z. Dubinsky and N. Stambler (Netherlands: Springer), 493-505.

Fabricius, K. E., Kluibenschedl, A., Harrington, L., Noonan, S., and De'Ath, G. (2015). In situ changes of tropical crustose coralline algae along carbon dioxide gradients. Sci. Rep. 5, 1-7. doi: 10.1038/srep09537

Falkowski, P. G., and Kolber, Z. (1995). Variations in chlorophyll fluorescence yields in phytoplankton in the world oceans. Aust. J. Plant Physiol. 22, 341-355. doi: 10.1071/PP9950341

Fernandes de Barros Marangoni, L., Ferrier-Pagès, C., Rottier, C., Bianchini, A., and Grover, R. (2020). Unravelling the different causes of nitrate and ammonium effects on coral bleaching. Sci. Rep. 10:11975. doi: 10.1038/ s41598-020-68916-0

Ferrier-Pagès, C., Gevaert, F., Reynaud, S., Beraud, E., Menu, D., Janquin, M.-A., et al. (2013). In situ assessment of the daily primary production of the temperate symbiotic coral Cladocora caespitosa. Limnol. Oceanogr. 58, 1409-1418. doi: 10.4319/lo.2013.58.4.1409

Finelli, C. M., Helmuth, B. S. T., Pentcheff, N. D., and Wethey, D. S. (2006). Water flow influences oxygen transport and photosynthetic efficiency in corals. Coral Reefs 25, 47-57. doi: 10.1007/s00338-005-0055-8

Finelli, C. M., Helmuth, B. S. T., Pentcheff, N. D., and Wethey, D. S. (2007). Intracolony variability in photosynthesis by corals is affected by water flow: role of oxygen flux. Mar. Ecol. Prog. Ser. 349, 103-110. doi: 10.3354/meps 07101

Frade, P. R., Englebert, N., Faria, J., Visser, P. M., and Bak, R. P. M. (2008). Distribution and photobiology of Symbiodinium types in different light environments for three colour morphs of the coral Madracis pharensis: is there more to it than total irradiance? Coral Reefs 27, 913-925. doi: 10.1007/ s00338-008-0406-3

Franklin, D., Hoegh-Guldberg, O., Jones, R., and Berges, J. (2004). Cell death and degeneration in the symbiotic dinoflagellates of the coral Stylophora pistillata during bleaching. Mar. Ecol. Prog. Ser. 272, 117-130. doi: 10.3354/ meps 272117

Galloway, J. N., Dentener, F. J., Capone, D. G., Boyer, E. W., Howarth, R. W., Seitzinger, S. P., et al. (2004). Nitrogen cycles: past, present, and future. Biogeochemistry 70, 153-226. doi: 10.1007/s10533-004-0370-0

Gardella, D. J., and Edmunds, P. J. (1999). The oxygen microenvironment adjacent to the tissue of the scleractinian Dichocoenia stokesii and its effects on symbiont metabolism. Mar. Biol. 135, 289-295. doi: 10.1007/s002270050626

Gattuso, J.-P., Yellowlees, D., and Lesser, M. (1993). Depth-and light-dependent variation of carbon partitioning and utilization in the zooxanthellate scleractinian coral Stylophora pistillata. Mar. Ecol. Prog. Ser. 92, 267-276. doi: $10.3354 /$ meps092267

Gevaert, F., Delebecq, G., Menu, D., and Brutier, L. (2011). A fully automated system for measurements of photosynthetic oxygen exchange under immersed conditions: an example of its use in Laminaria digitata (Heterokontophyta: Phaeophyceae). Limnol. Oceanogr. Methods 9, 361-379. doi: 10.4319/ lom.2011.9.361

Gorbunov, M. Y., Falkowski, P. G., and Kolber, Z. S. (2000). Measurement of photosynthetic parameters in benthic organisms in situ using a SCUBAbased fast repetition rate fluorometer. Limnol. Oceanogr. 45, 242-245. doi: 10.4319/lo.2000.45.1.0242

Goulletquer, P., Gros, P., Boeuf, G., and Weber, J. (2014). "Status and trends," in Biodiversity in the Marine Environment. Netherlands: Springer, 21-84.

Gruber, N. (2011). Warming up, turning sour, losing breath: ocean biogeochemistry under global change. Philos. Trans. R. Soc. A Math. Phys. Eng. Sci. 369, 1980-1996. doi: 10.1098/rsta.2011.0003

Haas, A. F., Nelson, C. E., Rohwer, F., Wegley-Kelly, L., Quistad, S. D., Carlson, C. A., et al. (2013). Influence of coral and algal exudates on microbially mediated reef metabolism. PeerJ 2013:e108. doi: 10.7717/ peerj.108

Hannah, L. (2016). "Impacts of anthropogenic $\mathrm{CO}_{2}$ and climate change on the biology of terrestrial and marine systems," in Wildlife Toxicology: Emerging Contaminant and Biodiversity Issues. eds. R. J. Kendall, T. E. Lacher, G. C. Cobb, S. B. Cox and T. E. Lacher (Boca Raton, Florida: CRC Press), 165-190.

Heery, E. C., Hoeksema, B. W., Browne, N. K., Reimer, J. D., Ang, P. O., Huang, D., et al. (2018). Urban coral reefs: degradation and resilience of 
hard coral assemblages in coastal cities of east and Southeast Asia. Mar. Pollut. Bull. 135, 654-681. doi: 10.1016/j.marpolbul.2018.07.041

Hill, R., Brown, C. M., DeZeeuw, K., Campbell, D. A., and Ralph, P. J. (2011). Increased rate of D1 repair in coral symbionts during bleaching is insufficient to counter accelerated photo-inactivation. Limnol. Oceanogr. 56, 139-146. doi: $10.4319 / 10.2011 .56 .1 .0139$

Hoegh-Guldberg, O. (2014). Coral reefs in the anthropocene: persistence or the end of the line? Geol. Soc. Spec. Publ. 395, 167-183. doi: 10.1144/ SP395.17

Hoegh-Guldberg, O., Mumby, P. J., Hooten, A. J., Steneck, R. S., Greenfield, P., Gomez, E., et al. (2007). Coral reefs under rapid climate change and ocean acidification. Science 318, 1737-1742. doi: 10.1126/science.1152509

Hoogenboom, M. O., Campbell, D. A., Beraud, E., DeZeeuw, K., and Ferrier-Pagès, C. (2012). Effects of light, food availability and temperature stress on the function of photosystem II and photosystem I of coral symbionts. PLoS One 7:e30167. doi: 10.1371/journal.pone.0030167

Hughes, T. P., Anderson, K. D., Connolly, S. R., Heron, S. F., Kerry, J. T., Lough, J. M., et al. (2018). Spatial and temporal patterns of mass bleaching of corals in the Anthropocene. Science 359, 80-83. doi: 10.1126/science.aan8048

Hughes, T. P., Barnes, M. L., Bellwood, D. R., Cinner, J. E., Cumming, G. S., Jackson, J. B. C., et al. (2017a). Coral reefs in the Anthropocene. Nature 546, 82-90. doi: 10.1038/nature22901

Hughes, T. P., Bellwood, D. R., Baird, A. H., Brodie, J., Bruno, J. F., and Pandolfi, J. M. (2011). Shifting base-lines, declining coral cover, and the erosion of reef resilience: comment on Sweatman et al. (2011). Coral Reefs 30, 653-660. doi: 10.1007/s00338-011-0787-6

Hughes, T. P., Kerry, J. T., Álvarez-Noriega, M., Álvarez-Romero, J. G., Anderson, K. D., Baird, A. H., et al. (2017b). Global warming and recurrent mass bleaching of corals. Nature 543, 373-377. doi: 10.1038/nature21707

Hughes, T. P., Kerry, J. T., Baird, A. H., Connolly, S. R., Chase, T. J., Dietzel, A., et al. (2019). Global warming impairs stock-recruitment dynamics of corals. Nature 568, 387-390. doi: 10.1038/s41586-019-1081-y

Hume, B. C. C., Voolstra, C. R., Arif, C., D’Angelo, C., Burt, J. A., Eyal, G., et al. (2016). Ancestral genetic diversity associated with the rapid spread of stress-tolerant coral symbionts in response to holocene climate change. Proc. Natl. Acad. Sci. U. S. A. 113, 4416-4421. doi: 10.1073/pnas.1601910113

Jones, A., Berkelmans, R., van Oppen, M. J., Mieog, J., and Sinclair, W. (2008). A community change in the algal endosymbionts of a scleractinian coral following a natural bleaching event: field evidence of acclimatization. Proc. R. Soc. B Biol. Sci. 275, 1359-1365. doi: 10.1098/rspb.2008.0069

Jones, R., Giofre, N., Luter, H. M., Neoh, T. L., Fisher, R., and Duckworth, A. (2020). Responses of corals to chronic turbidity. Sci. Rep. 10:4762. doi: 10.1038/s41598-020-61712-w

Kenkel, C. D., Traylor, M. R., Wiedenmann, J., Salih, A., and Matz, M. V. (2011). Fluorescence of coral larvae predicts their settlement response to crustose coralline algae and reflects stress. Proc. R. Soc. B Biol. Sci. 278, 2691-2697. doi: 10.1098/rspb.2010.2344

Kerrison, P., Hall-Spencer, J. M., Suggett, D. J., Hepburn, L. J., and Steinke, M. (2011). Assessment of $\mathrm{pH}$ variability at a coastal $\mathrm{CO}_{2}$ vent for ocean acidification studies. Estuar. Coast. Shelf Sci. 94, 129-137. doi: 10.1016/j.ecss.2011.05.025

Kline, D. I., Teneva, L., Schneider, K., Miard, T., Chai, A., Marker, M., et al. (2012). A short-term in situ $\mathrm{CO}_{2}$ enrichment experiment on Heron Island (GBR). Sci. Rep. 2, 1-9. doi: 10.1038/srep00413

Knowlton, N., Brainard, R. E., Fisher, R., Moews, M., Plaisance, L., and Caley, M. J. (2010). "Coral reef biodiversity," in Life in the World's Oceans. ed. A. D. McIntyre (Oxford, UK: Wiley-Blackwell), 65-78.

Kromkamp, J. C., and Forster, R. M. (2003). The use of variable fluorescence measurements in aquatic ecosystems: differences between multiple and single turnover measuring protocols and suggested terminology. Eur. J. Phycol. 38, 103-112. doi: 10.1080/0967026031000094094

Kuffner, I. B., Lidz, B. H., Hudson, J. H., and Anderson, J. S. (2015). A century of ocean warming on Florida keys coral reefs: historic in situ observations. Estuar. Coasts 38, 1085-1096. doi: 10.1007/s12237-014-9875-5

Kuhl, M., Cohen, Y., Dalsgaard, T., Jorgensen, B. B., and Revsbech, N. P. (1995). Microenvironment and photosynthesis of zooxanthellae in scleractinian corals studied with microsensors for 02, $\mathrm{pH}$ and light. Mar. Ecol. Prog. Ser. 117, 159-172. doi: 10.3354/meps117159

LaJeunesse, T. C., Parkinson, J. E., Gabrielson, P. W., Jeong, H. J., Reimer, J. D., Voolstra, C. R., et al. (2018). Systematic revision of Symbiodiniaceae highlights the antiquity and diversity of coral endosymbionts. Curr. Biol. 28, 2570.e6-2580.e6. doi: 10.1016/j.cub.2018.07.008

Lesser, M., and Gorbunov, M. (2001). Diurnal and bathymetric changes in chlorophyll fluorescence yields of reef corals measured in situ with a fast repetition rate fluorometer. Mar. Ecol. Prog. Ser. 212, 69-77. doi: 10.3354/ meps 212069

Lesser, M. P., Stat, M., and Gates, R. D. (2013). The endosymbiotic dinoflagellates (Symbiodinium sp.) of corals are parasites and mutualists. Coral Reefs 32, 603-611. doi: 10.1007/s00338-013-1051-Z

Levy, O., Achituv, Y., Yacobi, Y. Z., Dubinsky, Z., and Stambler, N. (2006). Diel "tuning" of coral metabolism: physiological responses to light cues. $J$. Exp. Biol. 209, 273-283. doi: 10.1242/jeb.01983

Levy, O., Dubinsky, Z., and Achituv, Y. (2003). Photobehavior of stony corals: responses to light spectra and intensity. J. Exp. Biol. 206, 4041-4049. doi: 10.1242/jeb.00622

Levy, O., Dubinsky, Z., Schneider, K., Achituv, Y., Zakai, D., and Gorbunov, M. Y. (2004). Diurnal hysteresis in coral photosynthesis. Mar. Ecol. Prog. Ser. 268, 105-117. doi: 10.3354/meps268105

Lilley, R. M., Ralph, P. J., and Larkum, A. W. D. (2010). The determination of activity of the enzyme Rubisco in cell extracts of the dinoflagellate alga Symbiodinium sp. by manganese chemiluminescence and its response to short-term thermal stress of the alga. Plant Cell Environ. 33, 995-1004. doi: $10.1111 / j .1365-3040.2010 .02121 . x$

Loiola, M., Cruz, I. C. S., Lisboa, D. S., Mariano-Neto, E., Leão, Z. M. A. N., Oliveira, M. D. M., et al. (2019). Structure of marginal coral reef assemblages under different turbidity regime. Mar. Environ. Res. 147, 138-148. doi: 10.1016/j.marenvres.2019.03.013

Lombardi, M. R., Lesser, M. P., and Gorbunov, M. Y. (2000). Fast repetition rate (FRR) fluorometry: variability of chlorophyll a fluorescence yields in colonies of the corals, Montastraea faveolata (w.) and Diploria labyrinthiformes (h.) recovering from bleaching. J. Exp. Mar. Biol. Ecol. 252, 75-84. doi: 10.1016/S0022-0981(00)00238-0

Long, M. H., Berg, P., de Beer, D., and Zieman, J. C. (2013). In situ coral reef oxygen metabolism: an Eddy correlation study. PLoS One 8:e58581. doi: 10.1371/journal.pone.0058581

Mass, T., Brickner, I., Hendy, E., and Genin, A. (2011). Enduring physiological and reproductive benefits of enhanced flow for a stony coral. Limnol. Oceanogr. 56, 2176-2188. doi: 10.4319/lo.2011.56.6.2176

Mass, T., Genin, A., Shavit, U., Grinstein, M., and Tchernov, D. (2010). Flow enhances photosynthesis in marine benthic autotrophs by increasing the efflux of oxygen from the organism to the water. Proc. Natl. Acad. Sci. U. S. A. 107, 2527-2531. doi: 10.1073/pnas.0912348107

McGillis, W. R., Langdon, C., Loose, B., Yates, K. K., and Corredor, J. (2011). Productivity of a coral reef using boundary layer and enclosure methods. Geophys. Res. Lett. 38, 1-15. doi: 10.1029/2010GL046179

McMahon, A., Santos, I. R., Schulz, K. G., Cyronak, T., and Maher, D. T. (2018). Determining coral reef calcification and primary production using automated alkalinity, $\mathrm{pH}$ and $\mathrm{pCO}_{2}$ measurements at high temporal resolution. Estuar. Coast. Shelf Sci. 209, 80-88. doi: 10.1016/j.ecss.2018.04.041

Meléndez, M., Salisbury, J., Gledhill, D., Langdon, C., Morell, J. M., Manzello, D., et al. (2020). Seasonal variations of carbonate chemistry at two Western Atlantic coral reefs. J. Geophys. Res. Ocean. 125:e2020JC016108. doi: 10.1029/2020JC016108

Muscatine, L. (1998). "The role of symbiotic algae in carbon and energy flux in reef corals," in Ecosystems of the World. ed. Z. Dubinsky (Amsterdam: Elsevier), 75-87.

Nakamura, T., and Nakamori, T. (2007). A geochemical model for coral reef formation. Coral Reefs 26, 741-755. doi: 10.1007/s00338-007-0262-6

Nakamura, T., and Nakamori, T. (2009). Estimation of photosynthesis and calcification rates at a fringing reef by accounting for diurnal variations and the zonation of coral reef communities on reef flat and slope: a case study for the Shiraho reef, Ishigaki Island, Southwest Japan. Coral Reefs 28, 229-250. doi: 10.1007/s00338-008-0454-8

Oh, T., Sermsripong, J., and Hicks, B. W. (2020). Using scuba for in situ determination of chlorophyll distributions in corals by underwater near infrared fluorescence imaging. J. Mar. Sci. Eng. 8:53. doi: 10.3390/jmse8010053

Okamoto, M., Nojima, S., Furushima, Y., and Nojima, H. (2005). Evaluation of coral bleaching condition in situ using an underwater pulse amplitude modulated fluorometer. Fish. Sci. 71, 847-854. doi: 10.1111/j.14442906.2005.01036.x 
Okazaki, R. R., Swart, P. K., and Langdon, C. (2013). Stress-tolerant corals of Florida Bay are vulnerable to ocean acidification. Coral Reefs 32, 671-683. doi: 10.1007/s00338-013-1015-3

Page, H. N., Courtney, T. A., Collins, A., De Carlo, E. H., and Andersson, A. J. (2017). Net community metabolism and seawater carbonate chemistry scale non-intuitively with coral cover. Front. Mar. Sci. 4:161. doi: 10.3389/fmars.2017.00161

Pandolfi, J. M., Connolly, S. R., Marshall, D. J., and Cohen, A. L. (2011). Projecting coral reef futures under global warming and ocean acidification. Science 333, 418-422. doi: 10.1126/science.1204794

Patterson, M. R., Sebens, K. P., and Olson, R. R. (1991). In situ measurements of flow effects on primary production and dark respiration in reef corals. Limnol. Oceanogr. 36, 936-948. doi: 10.4319/lo.1991.36.5.0936

Peixoto, R. S., Rosado, P. M., de Leite, D. C. A., Rosado, A. S., and Bourne, D. G. (2017). Beneficial microorganisms for corals (BMC): proposed mechanisms for coral health and resilience. Front. Microbiol. 8:341. doi: 10.3389/ fmicb.2017.00341

Piniak, G. A., and Storlazzi, C. D. (2008). Diurnal variability in turbidity and coral fluorescence on a fringing reef flat: Southern Molokai, Hawaii. Estuar. Coast. Shelf Sci. 77, 56-64. doi: 10.1016/j.ecss.2007.08.023

Platz, M. C., Takeshita, Y., Bartels, E., and Arias, M. E. (2020). Evaluating the potential for autonomous measurements of net community production and calcification as a tool for monitoring coral restoration. Ecol. Eng. 158:106042. doi: 10.1016/j.ecoleng.2020.106042

Pramneechote, P., Sinutok, S., Wongkamhaeng, K., and Chotikarn, P. (2020). An assessment of the net ecosystem metabolism and respiration of a tropical coral reef. Appl. Ecol. Env. Res. 18, 1863-1881. doi: 10.15666/aeer/1801_18631881

Rädecker, N., Pogoreutz, C., Gegner, H. M., Cárdenas, A., and Roth, F. (2021). Heat stress destabilizes symbiotic nutrient cycling in corals. Proc. Natl. Acad. Sci. U. S. A. 118:e2022653118. doi: 10.1073/pnas.2022653118

Ralph, P., Gademann, R., Larkum, A., and Schreiber, U. (1999). In situ underwater measurements of photosynthetic activity of coral zooxanthellae and other reef-dwelling dinoflagellate endosymbionts. Mar. Ecol. Prog. Ser. 180, 139-147. doi: $10.3354 /$ meps 180139

Ralph, P. J., Schreiber, U., Gademann, R., Kühl, M., and Larkum, A. W. D. (2005). Coral photobiology studied with a new imaging pulse amplitude modulated fluorometer. J. Phycol. 41, 335-342. doi: 10.1111/j.15298817.2005.04034.x

Ramesh, C. H., Koushik, S., Shunmugaraj, T., and Ramana Murthy, M. V. (2019). A rapid in situ fluorescence census for coral reef monitoring. Reg. Stud. Mar. Sci. 28:100575. doi: 10.1016/j.rsma.2019.100575

Randall, C. J., and Szmant, A. M. (2009). Elevated temperature affects development, survivorship, and settlement of the Elkhorn coral, Acropora palmata (Lamarck 1816). Biol. Bull. 217, 269-282. doi: 10.1086/BBLv217n3p269

Ray, C. G. (1988). "Ecological diversity in coastal zones and oceans," in Biodiversity. eds. E. O. Wilson and F. M. Peter (Washington: National Academies Press (US)).

Roberts, C. M., McClean, C. J., Veron, J. E. N., Hawkins, J. P., Allen, G. R., McAllister, D. E., et al. (2002). Marine biodiversity hotspots and conservation priorities for tropical reefs. Science 295, 1280-1284. doi: 10.1126/science. 1067728

Roder, C., Wu, Z., Richter, C., and Zhang, J. (2013). Coral reef degradation and metabolic performance of the scleractinian coral Porites lutea under anthropogenic impact along the NE coast of Hainan Island, South China Sea. Cont. Shelf Res. 57, 123-131. doi: 10.1016/j.csr.2012.11.017

Rohwer, F., Seguritan, V., Azam, F., and Knowlton, N. (2002). Diversity and distribution of coral-associated bacteria. Mar. Ecol. Prog. Ser. 243, 1-10. doi: $10.3354 /$ meps 243001

Rosenberg, E., Koren, O., Reshef, L., Efrony, R., and Zilber-Rosenberg, I. (2007). The role of microorganisms in coral health, disease and evolution. Nat. Rev. Microbiol. 5, 355-362. doi: 10.1038/nrmicro1635

Roth, M. S., and Deheyn, D. D. (2013). Effects of cold stress and heat stress on coral fluorescence in reef-building corals. Sci. Rep. 3, 1-8. doi: 10.1038/ srep01421

Roth, F., Rädecker, N., Carvalho, S., Duarte, C. M., Saderne, V., Anton, A., et al. (2020). High summer temperatures amplify functional differences between coral- and algae-dominated reef communities. Ecology 102:e03226. doi: $10.1002 /$ ecy.3226

Roth, F., Wild, C., Carvalho, S., Rädecker, N., Voolstra, C. R., Kürten, B., et al. (2019). An in situ approach for measuring biogeochemical fluxes in structurally complex benthic communities. Methods Ecol. Evol. 10, 712-725. doi: 10.1111/2041-210X.13151

Rovelli, L., Attard, K. M., Bryant, L. D., Flögel, S., Stahl, H., Roberts, J. M., et al. (2015). Benthic $\mathrm{O}_{2}$ uptake of two cold-water coral communities estimated with the non-invasive eddy correlation technique. Mar. Ecol. Prog. Ser. 525, 97-104. doi: 10.3354/meps 11211

Salih, A., Larkum, A., Cox, G., Kühl, M., and Hoegh-Guldberg, O. (2000). Fluorescent pigments in corals are photoprotective. Nature 408, 850-853. doi: $10.1038 / 35048564$

Sawall, Y., Teichberg, M. C., Seemann, J., Litaay, M., Jompa, J., and Richter, C. (2011). Nutritional status and metabolism of the coral Stylophora subseriata along a eutrophication gradient in Spermonde Archipelago (Indonesia). Coral Reefs 30, 841-853. doi: 10.1007/s00338-011-0764-0

Schneider, K., Levy, O., Dubinsky, Z., and Erez, J. (2009). In situ diel cycles of photosynthesis and calcification in hermatypic corals. Limnol. Oceanogr. 54, 1995-2002. doi: 10.4319/lo.2009.54.6.1995

Schreiber, U., Schliwa, U., and Bilger, W. (1986). Continuous recording of photochemical and non-photochemical chlorophyll fluorescence quenching with a new type of modulation fluorometer. Photosynth. Res. 10, 51-62. doi: $10.1007 /$ BF00024185

Shashar, N., Cohen, Y., and Loya, Y. (1993). Extreme diel fluctuations of oxygen in diffusive boundary layers surrounding stony corals. Biol. Bull. 185, 455-461. doi: $10.2307 / 1542485$

Shaw, E. C., Mcneil, B. I., Tilbrook, B., Matear, R., and Bates, M. L. (2013). Anthropogenic changes to seawater buffer capacity combined with natural reef metabolism induce extreme future coral reef $\mathrm{CO}_{2}$ conditions. Glob. Chang. Biol. 19, 1632-1641. doi: 10.1111/gcb.12154

Shaw, E. C., Phinn, S. R., Tilbrook, B., and Steven, A. (2014). Comparability of slack water and lagrangian flow respirometry methods for community metabolic measurements. PLoS One 9:e112161. doi: 10.1371/journal. pone.0112161

Shaw, E. C., Phinn, S. R., Tilbrook, B., and Steven, A. (2015). Natural in situ relationships suggest coral reef calcium carbonate production will decline with ocean acidification. Limnol. Oceanogr. 60, 777-788. doi: 10.1002/ lno. 10048

Shepard, A., Dinsmore, D., Miller, S., Cooper, C., and Wicklund, R. (1996). Aquarius undersea laboratory: the next generation. Available at: archive. rubicon-foundation.org/xmlui/handle/123456789/4703 (Accessed July 14, 2020).

Silbiger, N. J., Nelson, C. E., Remple, K., Sevilla, J. K., Quinlan, Z. A., Putnam, H. M., et al. (2018). Nutrient pollution disrupts key ecosystem functions on coral reefs. Proc. R. Soc. B Biol. Sci. 285, 2-10. doi: 10.1098/ rspb.2017.2718

Srednick, G., Bergman, J. L., Doo, S. S., Hawthorn, M., Ferree, J., Rojas, R., et al. (2020). Shallow coral reef free ocean carbon enrichment: novel in situ flumes to manipulate $\mathrm{pCO}_{2}$ on shallow tropical coral reef communities. Limnol. Oceanogr. Methods 18, 116-128. doi: 10.1002/lom3.10349

Suggett, D. J., Kikuchi, R. K. P., Oliveira, M. D. M., Spanó, S., Carvalho, R., and Smith, D. J. (2012). Photobiology of corals from Brazil's near-shore marginal reefs of Abrolhos. Mar. Biol. 159, 1461-1473. doi: 10.1007/ s00227-012-1925-6

Suggett, D. J., Oxborough, K., Baker, N. R., MacIntyre, H. L., Kana, T. M., and Geider, R. J. (2003). Fast repetition rate and pulse amplitude modulation chlorophyll $a$ fluorescence measurements for assessment of photosynthetic electron transport in marine phytoplankton. Eur. J. Phycol. 38, 371-384. doi: 10.1080/09670260310001612655

Takeshita, Y., Cyronak, T., Martz, T. R., Kindeberg, T., and Andersson, A. J. (2018). Coral reef carbonate chemistry variability at different functional scales. Front. Mar. Sci. 5:175. doi: 10.3389/fmars.2018.00175

Takeshita, Y., McGillis, W., Briggs, E. M., Carter, A. L., Donham, E. M., Martz, T. R., et al. (2016). Assessment of net community production and calcification of a coral reef using a boundary layer approach. J. Geophys. Res. Ocean. 121, 5655-5671. doi: 10.1002/2016JC011886

Thompson, J. R., Rivera, H. E., Closek, C. J., and Medina, M. (2015). Microbes in the coral holobiont: partners through evolution, development, and ecological interactions. Front. Cell. Infect. Microbiol. 4:176. doi: 10.3389/fcimb.2014.00176

Torres, O., Kwiatkowski, L., Sutton, A. J., Dorey, N., and Orr, J. C. (2021). Characterizing mean and extreme diurnal variability of ocean $\mathrm{CO}_{2}$ system variables across marine environments. Geophys. Res. Lett. 48:e2020GL090228. doi: $10.1029 / 2020$ GL090228 
Treibitz, T., Neal, B. P., Kline, D. I., Beijbom, O., Roberts, P. L. D., Mitchell, B. G., et al. (2015). Wide field-of-view fluorescence imaging of coral reefs. Sci. Rep. 5:7694. doi: 10.1038/srep07694

Van Zanten, B. T., Van Beukering, P. J. H., and Wagtendonk, A. J. (2014). Coastal protection by coral reefs: a framework for spatial assessment and economic valuation. Ocean Coast. Manag. 96, 94-103. doi: 10.1016/j. ocecoaman.2014.05.001

Wangpraseurt, D., Larkum, A. W. D., Ralph, P. J., and Kühl, M. (2012a). Light gradients and optical microniches in coral tissues. Front. Microbiol. 3:316. doi: $10.3389 /$ fmicb.2012.00316

Wangpraseurt, D., Polerecky, L., Larkum, A. W. D., Ralph, P. J., Nielsen, D. A., Pernice, M., et al. (2014). The in situ light microenvironment of corals. Limnol. Oceanogr. 59, 917-926. doi: 10.4319/lo.2014.59.3.0917

Wangpraseurt, D., Weber, M., Røy, H., Polerecky, L., de Beer, D., Suharsono, et al. (2012b). In situ oxygen dynamics in coral-algal interactions. PLoS One 7:e31192. doi: 10.1371/journal.pone.0031192

Weber, M., De Beer, D., Lott, C., Polerecky, L., Kohls, K., Abed, R. M. M., et al. (2012). Mechanisms of damage to corals exposed to sedimentation. Proc. Natl. Acad. Sci. U. S. A. 109, E1558-E1567. doi: 10.1073/ pnas. 1100715109

Weber, M., Faerber, P., Meyer, V., Lott, C., Eickert, G., Fabricius, K. E., et al. (2007). In situ applications of a new diver-operated motorized microsensor profiler. Environ. Sci. Technol. 41, 6210-6215. doi: 10.1021/ es070200b

Wijgerde, T., Silva, C. I. F., Scherders, V., Van Bleijswijk, J., and Osinga, R. (2014). Coral calcification under daily oxygen saturation and $\mathrm{pH}$ dynamics reveals the important role of oxygen. Biol. Open 3, 489-493. doi: 10.1242/ bio. 20147922

Wild, C., Rasheed, M., Jantzen, C., Cook, P., Struck, U., Huettel, M., et al. (2005). Benthic metabolism and degradation of natural particulate organic matter in carbonate and silicate reef sands of the northern Red Sea. Mar. Ecol. Prog. Ser. 298, 69-78. doi: 10.3354/meps 298069

Williams, D. E., Miller, M. W., Bright, A. J., Pausch, R. E., and Valdivia, A. (2017). Thermal stress exposure, bleaching response, and mortality in the threatened coral Acropora palmata. Mar. Pollut. Bull. 124, 189-197. doi: 10.1016/j.marpolbul.2017.07.001

Winters, G., Loya, Y., Röttgers, R., and Beer, S. (2003). Photoinhibition in shallow-water colonies of the coral Stylophora pistillata as measured in situ. Limnol. Oceanogr. 48, 1388-1393. doi: 10.4319/lo.2003.48.4.1388

Yates, K. K., and Halley, R. B. (2003). Measuring coral reef community metabolism using new benthic chamber technology. Coral Reefs 22, 247-255. doi: 10.1007/ s00338-003-0314-5

Yonge, S. C. M., Nicholls, A. G., and Yonge, M. J. (1932). The relationship between respiration in corals and the production of oxygen by their zooxanthellae. Sci. Reports/Gt. Barrier Reef Exped. 1, 213-251.

Zeebe, R. E., and Wolf-Gladrow, D. (2001). CO2 in Seawater: Equilibrium, Kinetics, Isotopes. Vol. 65. Amsterdam, Netherlands: Elsevier Oceanography, 360 .

Conflict of Interest: The authors declare that the research was conducted in the absence of any commercial or financial relationships that could be construed as a potential conflict of interest.

Copyright (c) 2021 Dellisanti, Chung, Chow, Wu, Wells and Chan. This is an open-access article distributed under the terms of the Creative Commons Attribution License (CC BY). The use, distribution or reproduction in other forums is permitted, provided the original author(s) and the copyright owner(s) are credited and that the original publication in this journal is cited, in accordance with accepted academic practice. No use, distribution or reproduction is permitted which does not comply with these terms. 